\title{
Can Electric Bicycles Enhance Leisure and Tourism Activities and City Happiness?
}

\author{
Hsiao-Hsien Lin ${ }^{1,2} \mathbb{D}$, Chih-Chien Shen ${ }^{3} \mathbb{D}$, I-Cheng Hsu ${ }^{4, *}$ and Pei-Yi Wu ${ }^{5, * \mathbb{D}}$ \\ 1 School of Physical Education, Jiaying University, Meizhou 514015, China; chrishome12001@yahoo.com.tw \\ 2 Department of Leisure Industry Management, National Chin-Yi University of Technology, \\ Taichung 41170, Taiwan \\ 3 Institute of Physical Education and Health, Yulin Normal University, 1303 Jiaoyu East Rd., \\ Yulin 537000, China; g169168@gmail.com \\ 4 Marketing and Distribution, Management Department, Tzu Chi University of Science and Technology, \\ Hualien 97004, Taiwan \\ 5 Language Center, National Dong Hwa University, No. 1, Sec. 2, Da Hsueh Rd., Shou-Feng 974, \\ Hualien 97401, Taiwan \\ * Correspondence: ichenghsu@gmail.com (I.-C.H.); clairewoow@gms.ndhu.edu.tw (P.-Y.W.)
}

Citation: Lin, H.-H.; Shen, C.-C.; Hsu, I.-C.; Wu, P.-Y. Can Electric Bicycles Enhance Leisure and Tourism Activities and City Happiness? Energies 2021, 14, 8144. https://doi.org/10.3390/en14238144

Academic Editor: Marcin Połom

Received: 27 October 2021

Accepted: 1 December 2021

Published: 4 December 2021

Publisher's Note: MDPI stays neutral with regard to jurisdictional claims in published maps and institutional affiliations.

Copyright: (C) 2021 by the authors. Licensee MDPI, Basel, Switzerland. This article is an open access article distributed under the terms and conditions of the Creative Commons Attribution (CC BY) license (https:// creativecommons.org/licenses/by/ $4.0 /)$.

\begin{abstract}
Using Meizhou City as an example, the aim of this study was to verify whether e-bike sharing systems can improve the convenience of engaging in leisure and tourism activities in cities, and thus increase residents' well-being. First, quantitative research was carried out to collect data on users' opinions. Then, qualitative research was carried out to obtain the opinions of experts. Finally, the investigation was conducted using multivariate review analysis. The results of the research showed that e-bikes should be classified based on electric quantity, the rental fee should be charged based on mileage, and the relevant corporate information should be integrated. It is also necessary to develop a software interface with functions for users to rent e-bikes and search for information related to consumption, leisure, and travel activities, and make promotion plans. Finally, people need to be encouraged to cycle to obtain the benefits of leisure and exercise. In this manner, the convenience of participation in leisure and tourism activities can be increased, people's physical and mental health will be substantially improved, and the happiness index of the people and the city will increase.
\end{abstract}

Keywords: green means of transportation; city happiness; experience value; leisure involvement; leisure satisfaction

\section{Introduction}

Advanced technology, effective transportation measures, good medical and health quality, and a healthy environment are essential for improving people's living conditions and quality, and provide stability and happiness to daily life [1]. However, significant investment is required to extract the existing resources of the Earth, and a large quantity of energy must be consumed to obtaining advanced technologies and facilities, to thus construct an ideal and suitable living environment [2,3]. Nevertheless, to respond to population growth and the rise in demand for leisure and tourism activities [3,4], it is necessary to increase the quantities of food, daily necessities and commodities, and facilities for public transportation, etc., to meet people's needs, and enable participation in leisure and tourism activities and the development of related industries $[5,6]$.

In particular, due to technological evolution, improving the safety, performance, and efficiency of transportation vehicles, and bridging the distance of social interaction, is an important key to accelerating the exchange of cultures, developing leisure and tourism activities, and promoting overall economic and industrial development [7-9]. However, although the development of advanced transportation technology has increased the levels of convenience in human life, housing, transportation and consumption $[9,10]$, 
it also consumes an enormous amount of energy, produces significant quantities of exhaust gas, oil pollution and domestic waste, and destroys the natural ecology and living environment [9-11]. Because China has been committed to improving economic development, improving people's quality of life, and promoting various developments, its carbon emissions have steadily increased [12]. China's carbon emissions grew from 197 million tons in 1954 to 150 billion tons in 2020 [13]. Although the effect was due to the impact of the pandemic, the Chinese government's white paper on China's climate change policies and actions stated that its carbon emissions fell by $48.4 \%$ in 2020 compared with 2005 [14]. However, statistics also show that China emitted about 2845 million tons of carbon dioxide in 2021, and is thus one of the main emitters of carbon emissions globally, second only to the United States [15]. These emissions have affected the climate, the natural ecology, and the living environment, and the degree of impact has gradually exceeded the positive economic benefits. The issue has been paid attention by the United Nations and other global organizations and governments [12-17], who have requested that the Chinese government to effectively reduce pollution and increase the usage rate of green transportation technologies and vehicles.

Green energy refers to energy that is produced through the cycle of nature, has an endless source, and does not cause environmental pollution in the process of production [18]. Green energy technology relates to the development of science and technology under the premise of maintaining the natural environment and resources, and reducing the negative impact of human activities $[19,20]$. In addition, the development of green energy transportation tools and technology can reduce energy consumption, and reduce exhaust emissions and pollution generated in the use of transportation, to achieve the sustainable development goals of social equity, economic viability, and environmental friendliness [21,22]. Therefore, replacing traditional vehicles with green alternatives, and encouraging their use by the public, will be one of the best means to reduce energy consumption and pollution, and maintain the natural ecology and human living environment.

Meizhou City is located in the northeast of Guangdong Province, China, at the junction of the three provinces of Guangdong, Fujian, and Jiangxi. Because the city is surrounded by mountains, is rich in natural resources, history, and ancient buildings, and has advanced industries and agriculture, it is highly attractive as a place to live, invest, and engage in leisure and tourism activities [23]. However, Meizhou is a mountainous city, and therefore inconvenient for transportation for trade and travel. Airports, railways, and road networks provide connections between the city and the outside world, and the city has been committed to promoting the leisure and tourism industry. However, it has also produced a large amount of carbon dioxide emissions as a result of improving economic development. Statistics show that Meizhou City emitted up to 9,403,200 tons of carbon dioxide emissions annually [24], indicating serious pollution in the form of carbon dioxide. In order to comply with the United Nations Paris Agreement, the Chinese government has clearly committed to reducing carbon dioxide emissions and maintaining the sustainable development of the planet. The Meizhou Municipal Government has followed the instruction of the central government and taken relevant measures to vigorously promote green modes of transportation to serve local people and tourists for the purpose of sustainable economic development, and leisure and tourism industries and activities, in addition to the improvement of the quality of life and health of the people. At present, Meizhou City has a population of about 3.87 million, and attracts at least 823,000 visitors annually [25], generating a revenue of USD 17.412 billion [26]. It can be seen that the current development of leisure and tourist industries has achieved remarkable results.

Many types of green vehicles exist. Buses, cars, and bicycles powered by electricity as the main kinetic energy are common green vehicles. Electric buses are currently one of the common forms of public transportation, and are also the main means of transportation for the public in China. However, the use of public transportation has been affected by the COVID-19 pandemic, which has not abated [27]. Although the routes of infection are clear, governments of various countries have taken preventive measures [28] and 
encouraged people to wear masks for self-protection [29]. In addition, protection has been provided via the development of several vaccines, administered by injections, and many experiments have been conducted and forms of epidemic tracking simultaneously implemented to ensure the efficacy of the vaccines [30,31]. However, due to the rapid mutation and spread of the coronavirus, it is highly infectious, and those who had taken two doses of vaccine may still be infected in the public environment [32]. Therefore, to avoid or reduce the risk of infection, people are unwilling to take public transportation [33]. As a result, people are less frequently engaging in outside activities, which has indirectly reduced consumption, caused a decline in industrial productivity, and restricted urban development. Therefore, it is important to develop safe, hygienic, and convenient public transportation, in order to reduce the risk of infection, and maintain people's leisure activities and consumption modes.

The design concept of e-bikes originated with bicycles. As a result of the advancement of science and technology, bicycles equipped with an electric motor, which may be activated to assist with or replace pedaling, has become a new form of transportation technology. A bicycle sharing system is a shared transportation service in which bicycles are shared by individuals $[34,35]$. China has implemented policies for e-bike sharing systems for many years, and there has been a sharp increase in usage and business opportunities [35]. At present, small batteries are used as energy sources, and facilities are established in open spaces. People can use their personal mobile phones and satellite positioning to check the parking locations and rental measures of the brand of equipment they want to use. They can also use their phones to talk to the customer service center, report failures, and learn about and obtain the latest preferential treatment [35], as shown in Figure 1. Currently, e-bike sharing systems are not only easy to operate, but also make it convenient for the users to search for and borrow e-bikes. Although the users of e-bike sharing systems still face a risk that they may contract COVID-19, compared with mass transportation, e-bike sharing systems allow users to separately borrow and return e-bikes, thus reducing their risk of infection [35-37]. In addition, these systems help decrease energy consumption, air pollution, and carbon emissions. The Chinese government intends to continue to provide people with safe transportation modes such as bicycle-sharing systems during the pandemic, thus allowing individuals to engage in leisure, tourism, and consumption activities, and to resume normal life and work. Statistics indicate there are currently more than 50 million e-bikes in China, and 1 million in Guangdong Province alone. These are used by people from all walks of life for work, study, travel, and leisure and entertainment activities [38]. The ridership is now 18.86 million, and the total turnover has reached USD 450 million [35,39]. The government has estimated that 59 million e-bikes will be needed for bicycle sharing systems in China by 2025, generating revenue of USD 3.0924 billion [35-39]. It is evident that e-bikes have performed a valuable function that has helped governments restore people's livelihood and economy, and are thus important for the public.

At present, to prevent the spread of coronavirus [39], the Chinese government expects to use the characteristics and functions of the e-bike system to allow the public to resume their normal life and leisure activities, restart the urban economy and restore social order [40], and build a safe, healthy, and happy city [40-44]. However, time is required to verify whether the implementation of a policy is effective [33] and to identify problems $[45,46]$, and users' experience is needed to understand the outcomes of policy implementation [47]. In addition, it is necessary to verify whether the characteristics and functions of e-bike sharing systems can really allow the public to resume normal life and leisure activities, and restart the urban economy, from the perspective of consumers and based on the value of facilities, leisure involvement, satisfaction, and well-being [47]. Therefore, the main purpose of this study was to understand the true effect of the government's policy to use e-bikes to achieve these aims, based on the people's experience of using the e-bike sharing system and their cognition of the value of facilities, leisure involvement, satisfaction, and well-being. 


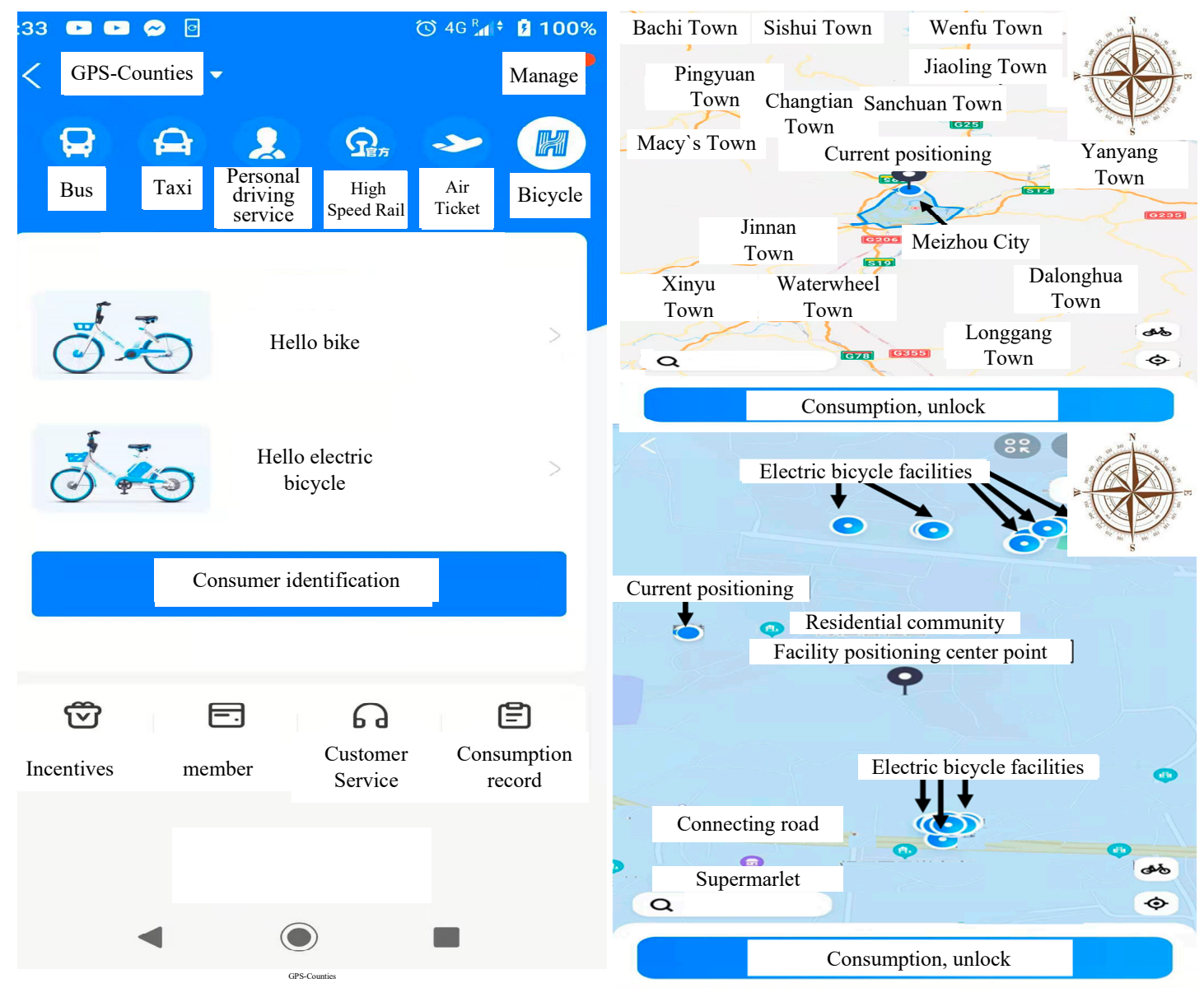

Figure 1. Description of the operation interface between an e-bike sharing system and mobile phone.

\section{Literature Review}

\subsection{Well-Being Cognition under City Happiness}

It is the unanimous goal of countries to provide their populations with City Happiness and achieve human sustainability. However, although many countries are currently are aiming to lift pandemic travel restrictions and foster a safe, healthy, and happy living environment [37], people from different backgrounds perceive well-being differently [48,49]. Therefore, we must first define the scope of well-being before we can continue to discuss how to foster the environment of a happy city. In a broad sense, well-being is a type of attitude and psychological perception, based on the positive development of personal life, and is also a complex and subjective concept $[48,49]$. Well-being is a kind of cognition of the current emotions and preferences measured using personal subjective feelings [50,51]. When the material needs of personal life are satisfied, and people's interaction with the atmosphere of the surrounding living environment is recognized [52-55], a feeling of well-being will be experienced.

In early research, scholars believed that economic indicators such as GDP could be used to measure well-being [56]. Subsequently, however, scholars stated that a complete well-being index should include health status, welfare status, and other social development [56]. Usually, well-being is determined from the perspective of personal experience, based on subjective, psychological, and social well-being $[48,49]$, through the experiences of life satisfaction, physical and mental health, and self-affirmation, according to the comparison between needs and expectations $[52,53]$. The most common problems regarding well-being relate to leisure behavior, social interaction, emotion, health, physical fitness, self-confidence, and sense of accomplishment $[55,56]$. Overall, to initially define and understand people's perception of well-being, the above indicators show the levels 
of well-being perceived by individuals. Therefore, we propose Hypothesis 1 based on the above inference, namely, that there are differences in people's perceptions of well-being.

\subsection{Amenities Experience Value and Well-Being Cognition}

Device sharing is an innovative market mechanism that combines public and personal information devices through technology and cloud computing to provide convenient mobility provisioning facilities and mechanisms for the public [57]. Moreover, the use of e-bike sharing systems currently appears to be a means to reduce the risk of infection when going out, and to foster a safe, healthy, and happy living environment [39]. Therefore, understanding people's perceptions of an e-bike sharing system will help to understand their confidence in the system. The amenities experience value refers to the user's experience of obtaining physical and psychological satisfaction from the amenities and their surroundings [58]. Usually, motivation exists before the desired behavior is undertaken. After comparison with past experience, a new experience is generated in terms of physiology and psychology, and finally becomes the personal perceived value of the amenities [59].

Although research has found that people from different backgrounds have different experiences and perceptions of the same facility [60], scholars believe that the evaluation of local building facilities, leisure, recreational activities, and space is carried out based on the user's experience of facilities, goods, or services [60,61]. Scholars believe that amenities experience value can be measured from emotional, logical, and practical perspectives [61]; judged from the perspectives of service superiority, return on investment, fun [62], education, escapism, and aesthetics [63,64]; and explored from the perspectives of aesthetic experience, information system quality, and commodity experience value [65]. Issues such as integrity, attractiveness, design style, environmental awareness, environmental knowledge, and relaxation have been previously explored [61-65]. In addition, if the people's experience value is higher, their positive psychological feeling will be better and their levels of well-being will also be higher [66]. It is obvious that judging users' experience value helps us to not only know their confidence in the system, but also understand their current happiness perception after using the system. Therefore, we propose Hypothesis 2 based on the above inferences, namely, that people perceive different amenities and environmental experience values of e-bike sharing systems. In addition, the hypothesis that the amenities and environmental experience values have a positive and significant impact on the perception of well-being is Hypothesis 5.

\subsection{Leisure Involvement and Well-Being Cognition}

The e-bike sharing system exhibits the characteristics of safety and convenience, indirectly performs functions for leisure and travel, and helps improve health, happiness, and safety. This system is one of the basic indicators of happy city [37]. However, the main reason for fostering a healthy and happy atmosphere is to ensure that people have a comfortable life and regularly partake in leisure activities. Therefore, knowing the frequency with which people use e-bikes for leisure activities will improve our understanding. Involvement refers to the inner experience, which is a form of perception [67]. Leisure involvement refers to a psychological state in which individuals are affected by internal and external factors, such as inner core values, continuity, physical environment or products, services, and communication, which affect the decision to participate in leisure [68]. Leisure involvement helps individuals undertake valuable leisure activities.

Scholars believe that, although people of different backgrounds and leisure styles are significantly different from each other in terms of their degree of leisure involvement [69-71], their willingness to participate is affected by the degree of importance they attach to a certain thing or object $[68,72]$. The involvement and subsequent developmental influence can be understood according to the degree of correlation between the inner mental state and the outer situation or stimulus. This involvement can be divided into behavioral involvement and social involvement [69], which can be defined according to people's behaviors and attitudes, and separated into three dimensions-attractiveness, centrality, and 
self-expression. The psychological level of participation and feelings, the degree of affection and values, self-expression, the establishment of self-confidence, and attracting attention can then be used to explore the main influencing factors of leisure involvement [72-76]. The higher the degree of leisure involvement, the higher the degree of concentration [67], the better the leisure behavior and performance, the stronger the feeling of happiness and pleasure [71], the more obvious the improvement in the personal perception of positive physical and mental health, and the more significant the feeling of happiness [72-77]. It is clear that judging the degree of leisure involvement helps us understand not only the people's degree of involvement in the use of e-bike sharing systems for leisure and tourism activities, but also whether their happiness and well-being increase as a result. Therefore, we propose Hypothesis 3 based on the above inferences, namely, that there are differences in people's perceptions of leisure involvement in e-bike sharing systems. In addition, that hypothesis that leisure involvement has a positive and significant impact on the perception of well-being is Hypothesis 6 .

\subsection{Leisure Satisfaction and Well-Being Cognition}

Although using the characteristics and functions of e-bike sharing systems is currently being adopted to reduce the risk of infection and sustain livelihoods, and to revitalize economies [37], people usually use these facilities to engage in leisure and tourism activities before they can compare the positive and negative perceptions of their experiences. Therefore, carrying out a study based on the theory and perception of leisure satisfaction is the best means to verify whether an e-bike sharing system helps people to participate in leisure activities and obtain feelings of happiness. Leisure satisfaction refers to the cognition obtained by people during their leisure activities, after comparing their personal leisure experience with the actual environment experience [76]. When the actual leisure environment or the experience of the activity content meets personal expectations, the individual will be satisfied; otherwise, he/she will feel dissatisfaction [71].

Although people of different backgrounds are significantly different from each other in terms of their perceptions of leisure satisfaction $[72,78,79]$, the factors affecting leisure satisfaction can be explored from both internal and external aspects [80]. These aspects include those of physiology, psychology, education, aesthetics, social interaction, relaxation [81], education, and society [72]. Among these, the factors affecting leisure satisfaction can be obtained from activity content, self-confidence and physical fitness, physical and mental health, personal physical fitness, broadening knowledge, social interaction, self-exploration, relaxation, environmental experience, and feelings. Moreover, studies have shown that there are significant differences in leisure satisfaction cognition of people with different backgrounds [72,81]. The higher the cognition of leisure satisfaction, the higher the positive cognition obtained by the individual [71], the more the individual's inner needs, quality of life, and material conditions are satisfied, and the stronger the feeling of happiness perceived by the individual [72,80-82]. It is clear that judging people's degree of leisure satisfaction can help us understand their actual feelings of experiencing the e-bike sharing system for leisure and tourism activities, and whether their feelings of happiness and wellbeing will increase. Therefore, we propose Hypothesis 4 based on the above inferences, namely, that there are differences in the perceptions of leisure satisfaction with the e-bike sharing system. In addition, the hypothesis that leisure satisfaction has a positive and significant impact on the perception of well-being is Hypothesis 7.

In summary, the main purpose of this study was to verify that the Meizhou City government and the city's people have used the characteristics and functions of the e-bike sharing system as a means of transportation to create a safe and healthy leisure and tourism environment during the coronavirus pandemic [39], from the theoretical perspectives of amenity values, leisure involvement, satisfaction, and well-being [48-82], based on the literature mentioned above. An examination of the literature by the researchers showed that, among the current research topics on shared bicycles, previous studies mostly explored facility planning and consumer market potential [83-85]; cloud technology, energy, and 
riding trajectory data [86-88]; consumer choices and consumer satisfaction [89]; service quality [90]; and well-being [91,92]. It is clear that the topics and viewpoints of this study are novel. However, if different research methods are used and more extensive information can be gathered from different perspectives, more in-depth and subtle results can be obtained [45-47]. In summary, this study aimed to examine experience value, leisure involvement, satisfaction, and well-being. First, people's cognition of e-bike-related experience value, leisure involvement, satisfaction, and well-being were explored. Then, the influence of experience value, leisure involvement, satisfaction, and personal well-being after experiencing e-bikes was explored. Finally, analysis was conducted to verify whether e-bikes can improve the convenience of urban leisure and tourism activities, and achieve the happiness index goal of the people and the city. The results of this study will be helpful for governments to make policies and suggestions to allow people to resume normal lives, restart the urban economy, and restore social order, during and after the pandemic.

\section{Methods}

\subsection{Framework and Hypothesis}

Green public transportation vehicles are designed to provide public transportation services, reduce carbon emissions [12-17], and achieve pro-environmental goals [12-20]. However, as a result of the spread of the pandemic and the high risk of infection [35-37], people's willingness to go out and use public transportation has declined [27,32]. This has negative consequences for maintaining people's physical and mental health, and the state of the urban economy, resulting in a decline in well-being. An e-bike is mainly used by one person. It is convenient to use, travels fast, and is usually used for short-distance travel for leisure and tourism activities $[34,35]$. Thus, the Chinese government aims to promote e-bikes as one of the main public transportation vehicles in urban areas to help prevent the spread of COVID-19. It is hoped that this will allow people to resume normal life, thereby restarting urban economies and increase well-being.

However, there will be difference between the expected effect of the policy and the actual implementation effect $[45,47]$. In addition, it takes a long time to confirm this difference, and a clear direction and answer can only be obtained after collecting users' views [46]. According to the literature, it is reasonable to infer that the issue can be explored from theoretical frameworks such as happiness cognition [48-53], amenities experience value [57-66], leisure participation [68-77], and leisure satisfaction [71], by collecting data from multiple channels, and by using a variety of research methods for analysis [71-82]. In this manner, we can understood whether e-bikes can help people to resume normal life and restart economic development, and help improve the happiness of people and cities. The research framework is shown in Figure 2.

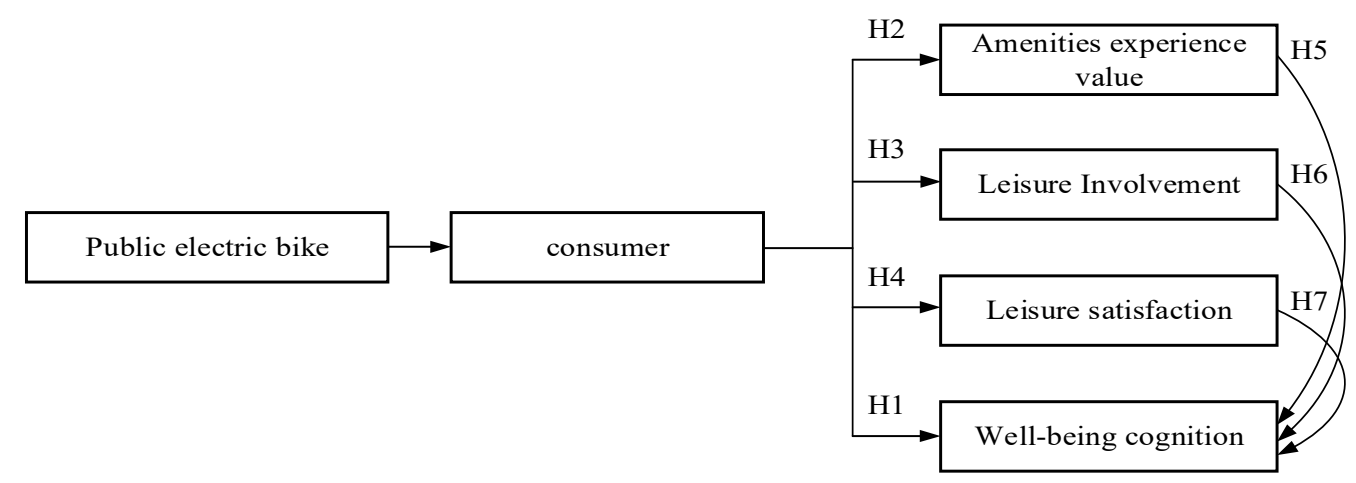

Figure 2. Study framework.

Based on the literature mentioned above and the study framework, seven hypotheses are proposed: 
Hypothesis 1 (H1). It is assumed that consumers' well-being cognition of the e-bike sharing system is inconsistent.

Hypothesis 2 (H2). It is assumed that consumers' cognition of amenities and environmental experience values of the e-bike sharing system is inconsistent.

Hypothesis 3 (H3). It is assumed that consumers' leisure involvement cognition of the e-bike sharing system is inconsistent.

Hypothesis 4 (H4). It is assumed that consumers' leisure satisfaction cognition of the e-bike sharing system is inconsistent.

Hypothesis 5 (H5). It is assumed that the amenities and environmental experience values and the well-being cognition have a positive and significant influence.

Hypothesis 6 (H6). It is assumed that leisure involvement and well-being cognition have a positive and significant influence.

Hypothesis 7 (H7). It is assumed that leisure satisfaction and well-being cognition have a positive and significant influence.

\subsection{Process and Methods}

This study aimed to examine the influence of using an e-bike sharing system to expand the transportation network of leisure and tourism activities, on the improvement in the happiness of the people and the city, based on consumers' cognition of amenities and environmental experience values, leisure involvement, satisfaction, and well-being. Although many studies have been conducted on the related theories and issues, few studies have been undertaken on urban public transportation, green energy, and e-bikes. Therefore, due to this absence in the literature, a mixed research method was adopted. First, the quantitative research method was used to increase the breadth of the research $[93,94]$, and then the qualitative research method was used to increase the research depth [95]. This approach can compensate for the shortcomings of the research methods or theories [96]. Furthermore, according to the literature, there are differences in the perceptions of experience value, leisure involvement, satisfaction, and well-being in different genders, age groups, and people with different education levels [48,49]. The $t$-test and analysis of variance (ANOVA) can be used to obtain results that take account of the interference factor of people's backgrounds [97,98]. Moreover, it has been confirmed that perceptions of experience value, leisure involvement, satisfaction, and well-being may interact with each other; the Pearson product-moment correlation coefficient (PPMCC) can be used to determine the strength of the correlation between variables $[97,99]$.

The researchers first edited the preliminary contents of the questionnaire based on relevant research [45-82], carried out field surveys, revised the questionnaire items, and invited three experts to check the validity of the questionnaire and confirm its objectives. Then, in August 2021, they distributed questionnaires on-site to collect enough responses to ensure a predictive sample, and used SPSS 26.0 statistical software to verify the feasibility of the questionnaire and confirm its content.

During the fieldwork period of September-October 2021, the research team used convenience sampling to distribute 100 questionnaires to respondents who expressed their willingness to participate. Using the Chinese online survey platform, Questionnaire Star, the snowball sampling method was used, and a cut-off of 800 total online questionnaires for respondents to recommend other people to participate in the survey. Finally, there were 800 valid questionnaires, with a recovery rate of $88.8 \%$. Next, basic statistics, the $t$-test, ANOVA, and the PPMCC test were used to analyze the questionnaire data. Then, the semi-structured interview method was used to collect the opinions of officials, experts, 
and residents based on the results of the questionnaire analysis. All data was collated in a rigorous, orderly, and logical manner, and valuable information was obtained using summarizing, organizing, and sorting methods [100]. Finally, the multiple comparison analysis testing was used to conduct a discussion in a multi-data and multi-perspective manner [101,102].

\subsection{Tools and Analysis}

The questionnaire is divided into two parts. The first part relates to background information, including gender (male, female), age group (under 20, 21-30, 31-40, 41-50, 51 and above), and education level (below junior high school, high school or vocational high school, junior college or university, graduate school or above). The second part comprises 31 questions on experience value, leisure involvement, leisure satisfaction, and well-being. It was designed with a Likert 5-point scale (1 point means very dissatisfied, 5 points very satisfied). After the questionnaire was edited, 3 experts were invited to conduct a review, and then 6 interviewees, including experts with expertise in research on tourism development and policy making, and people with experience in e-bike sharing systems, were invited to provide their opinions based on the results of subsequent data analysis. Related background and interview issues are shown in Table 1.

Table 1. Respondent's background information and an overview of the interview outline.

\begin{tabular}{|c|c|c|c|c|c|}
\hline Identity & Gender & $\begin{array}{l}\text { Residence Time/Years } \\
\text { of Work Experience }\end{array}$ & Identity & Gender & $\begin{array}{l}\text { Residence Time/Years } \\
\text { of Work Experience }\end{array}$ \\
\hline professor & Male & 15 & Tourist & Male & 12 \\
\hline professor & Female & 28 & Tourist & Female & 15 \\
\hline professor & Male & 22 & entrepreneur & Female & 35 \\
\hline Construct & \multicolumn{5}{|c|}{ Issues } \\
\hline $\begin{array}{l}\text { Impact of tourism } \\
\text { development }\end{array}$ & \multicolumn{5}{|c|}{$\begin{array}{l}\text { Please comment, how do you feel after sharing electric bicycle facilities and environmental } \\
\text { planning experience? } \\
\text { Please evaluate whether the planning of shared electric bicycle facilities has improved the benefits of } \\
\text { people's participation in leisure activities? Please explain why. } \\
\text { Please evaluate the effectiveness and satisfaction of using shared electric bicycle facilities to engage in } \\
\text { leisure activities? Please explain why. } \\
\text { Please comment on whether the decision to construct shared electric bicycle transportation in the city } \\
\text { will help the people to enhance their feelings of happiness, friendliness and happiness? }\end{array}$} \\
\hline
\end{tabular}

After experts and scholars checked the content validity, the formal questionnaire content was determined. Then, SPSS 26.0 statistical software was used for statistical verification and measurement. Scholars believe that a Kaiser-Meyer-Olkin (KMO) test result $>0.06$ and a $p$-value in the Bartlett test of less than $0.01(p<0.01)$ indicate that the scale is suitable for continuous factor analysis [103]. A detection result $\alpha$-value greater than 0.60 represents high reliability [104], and can be analyzed further. The analysis and discussion were conducted in the order of experience value, leisure involvement, leisure satisfaction, and well-being.

There were 16 questions about amenities and environmental experience value of the e-bike sharing system following editing based on the literature [57-66]. The analysis result showed that KMO was 0.940 , Bartlett's approximate $\chi 2$ value was 7474.005 , df was 120 , and the significance was $p<0.001$; thus, the data were suitable for factor analysis. The explainable variations of the scale were $29.450 \%, 26.548 \%$, and $20.396 \%$, and the total explained variation was $76.394 \%$. After factor analysis, good and reliable issues were retained. These were named as aesthetic experience (6 questions), information system quality (6 questions), and commodity experience value (4 questions). Among these, the $\alpha$ coefficient was $0.971-0.972$, and the total scale $\alpha$ coefficient was 0.974 . The above analysis results indicate that the items about amenities experience value in this questionnaire have high reliability. 
There were 9 questions about leisure involvement after editing based on the literature [68-77]. The analysis results showed that KMO was 0.909, and Bartlett's approximate $\chi 2$ value was 3836.646 , df was 36 , and the significance was $p<0.001$; thus, the data were suitable for factor analysis. The explainable variations of the scale were $31.955 \%$, $25.468 \%$, and $24.304 \%$, and the total explained variation was $81.728 \%$. After factor analysis, good and reliable issues were retained. They were named attractiveness (2 questions), centrality (4 questions), and self-expression (3 questions). Among these, the $\alpha$ coefficient was $0.948-0.953$, and the total scale $\alpha$ coefficient was 0.957 . The above analysis results indicate that the items about leisure involvement in this questionnaire have high reliability.

There were 12 questions about leisure satisfaction after the editing based on the literature [71-82]. The analysis results showed that KMO was 0.939, and Bartlett's approximate $\chi 2$ value was 4359.049 , df was 66 , and the significance was $p<0.001$; thus, the data were suitable for factor analysis. The explainable variations of the scale were $47.471 \%, 15.686 \%, 10.336 \%, 3.037 \%, 1.765 \%$, and $1.356 \%$, and the total explained variation was $79.652 \%$. After factor analysis, good and reliable issues were retained. They were named physiology (2 questions), psychology (2 questions), education (2 questions), social (2 questions), relaxation (2 questions), and aesthetics (2 questions). Among these, the $\alpha$ coefficient ranged from 0.940 to 0.948 , and the total scale $\alpha$ coefficient was 0.949 . The above analysis results indicate that the items about leisure involvement in the questionnaire have high reliability.

There were 6 questions about well-being cognition after the editing based on the literature [48-53]. The analysis results showed that KMO was 0.918, and Bartlett's approximate $\chi 2$ value was 2395.890 , df was 15 , and the significance was $p<0.001$; thus, the data were suitable for factor analysis. The explainable variations of the scale were $44.441 \%$, $33.907 \%$, and $3.161 \%$, and the total explained variation was $81.509 \%$. After factor analysis, good and reliable issues were retained. They were named as life satisfaction (2 questions), physical and mental health (2 questions), and self-affirmation (2 questions). Among these, the $\alpha$ coefficient was $0.948-0.953$, and the total scale $\alpha$ coefficient was 0.957 . The above analysis results indicate that the items about well-being cognition in the questionnaire have high reliability. As shown in Table 2.

Table 2. Questionnaire analysis form of facility experience value, leisure involvement, leisure satisfaction and wellbeing perception.

\begin{tabular}{|c|c|c|c|c|c|}
\hline Aspect & Subfactor & Issue & $\mathbf{M}$ & SD & Cronbach's $\alpha$ \\
\hline \multirow{16}{*}{$\begin{array}{c}\text { Facilities and } \\
\text { environmental } \\
\text { experience value }\end{array}$} & \multirow{6}{*}{$\begin{array}{l}\text { Aesthetic } \\
\text { experience }\end{array}$} & Product design feels comfortable & 4.00 & 0.758 & 0.971 \\
\hline & & Creative design & 4.00 & 0.812 & 0.971 \\
\hline & & good consumer experience & 4.05 & 0.799 & 0.971 \\
\hline & & Want to use other products & 4.05 & 0.804 & 0.972 \\
\hline & & Improve social identity & 3.94 & 0.889 & 0.971 \\
\hline & & Representing personal characteristics & 3.74 & 1.023 & 0.972 \\
\hline & \multirow{6}{*}{$\begin{array}{l}\text { Information } \\
\text { system quality }\end{array}$} & Clear navigation function & 3.95 & 0.793 & 0.971 \\
\hline & & System stability & 4.07 & 0.764 & 0.971 \\
\hline & & Clear information & 4.08 & 0.722 & 0.971 \\
\hline & & Reliable information & 4.06 & 0.742 & 0.971 \\
\hline & & Online instructions & 4.06 & 0.750 & 0.971 \\
\hline & & System communication is smooth & 4.03 & 0.810 & 0.972 \\
\hline & \multirow{4}{*}{$\begin{array}{l}\text { Commodity } \\
\text { experience } \\
\text { value }\end{array}$} & Great value for money & 4.01 & 0.809 & 0.971 \\
\hline & & Description in detail & 4.07 & 0.832 & 0.972 \\
\hline & & Good service & 4.06 & 0.783 & 0.971 \\
\hline & & Choose the right one & 4.04 & 0.813 & 0.971 \\
\hline
\end{tabular}


Table 2. Cont.

\begin{tabular}{|c|c|c|c|c|c|}
\hline Aspect & Subfactor & Issue & $\mathbf{M}$ & SD & Cronbach's $\alpha$ \\
\hline \multirow{9}{*}{$\begin{array}{c}\text { Leisure } \\
\text { involvement }\end{array}$} & \multirow[b]{2}{*}{ Attractiveness } & Important dependence & 3.99 & 0.901 & 0.950 \\
\hline & & Very satisfying and interesting & 4.08 & 0.819 & 0.953 \\
\hline & \multirow{4}{*}{ Centrality } & Like to use this tool for leisure & 4.11 & 0.819 & 0.951 \\
\hline & & Life is a big part & 3.89 & 0.990 & 0.952 \\
\hline & & play an important role & 3.96 & 0.918 & 0.948 \\
\hline & & Discuss chat topics & 4.02 & 0.926 & 0.953 \\
\hline & \multirow{3}{*}{ Self-expression } & Friends also choose the same product & 4.00 & 0.946 & 0.951 \\
\hline & & Can express one's own characteristics & 3.90 & 0.901 & 0.951 \\
\hline & & Normal and natural behavior & 4.03 & 0.852 & 0.951 \\
\hline \multirow{12}{*}{ Leisure satisfaction } & \multirow{2}{*}{ Physiological } & Heavy activity & 3.69 & 1.171 & 0.941 \\
\hline & & Like to engage in activities & 3.76 & 1.140 & 0.941 \\
\hline & \multirow{2}{*}{ Psychological } & Physical fitness is challenging & 3.86 & 1.111 & 0.941 \\
\hline & & Physical recovery & 3.88 & 1.075 & 0.942 \\
\hline & \multirow{2}{*}{ Educational } & Broaden horizons & 3.76 & 1.020 & 0.943 \\
\hline & & Learn new things through others & 3.90 & 1.098 & 0.941 \\
\hline & \multirow{2}{*}{ Social } & meet new friends & 3.91 & 1.152 & 0.952 \\
\hline & & Develop friendly relations & 3.97 & 1.138 & 0.953 \\
\hline & \multirow{2}{*}{ Relax } & Make me feel relaxed & 3.65 & 1.190 & 0.942 \\
\hline & & Can stabilize my mood & 3.75 & 1.137 & 0.941 \\
\hline & \multirow{2}{*}{ Aesthetics } & Publicly safe & 3.84 & 1.035 & 0.942 \\
\hline & & Well planned & 3.79 & 1.137 & 0.940 \\
\hline \multirow{6}{*}{ Well-being } & \multirow{2}{*}{$\begin{array}{l}\text { Life } \\
\text { satisfaction }\end{array}$} & Have more opportunities to participate in leisure & 4.07 & 0.803 & 0.937 \\
\hline & & Convenient for leisure planning & 4.09 & 0.790 & 0.948 \\
\hline & \multirow{2}{*}{$\begin{array}{l}\text { Physical and } \\
\text { mental health }\end{array}$} & Relaxation of body and mind & 4.13 & 0.876 & 0.944 \\
\hline & & Life correction & 3.98 & 0.905 & 0.942 \\
\hline & \multirow{2}{*}{$\begin{array}{l}\text { Self- } \\
\text { affirmation }\end{array}$} & I like to engage in leisure in this way & 4.13 & 0.797 & 0.935 \\
\hline & & Able to interact with others & 4.06 & 0.842 & 0.941 \\
\hline
\end{tabular}

\subsection{Objects, Scope and Limitations}

The topic of the study was the e-bike sharing system; the issues that were researched were experience value, leisure involvement, satisfaction, and well-being; and the aim was to explore the amenities and environmental experience value, leisure involvement satisfaction, and well-being cognition of local people in Meizhou City, Guangdong Province, China, regarding the e-bike sharing system.

The researchers first conducted field surveys and then collected questionnaires using convenience sampling methods, coupled with the online questionnaire platform to gather data. In addition, snowball sampling was used in which on-site respondents were trusted to recommend volunteers to participate in the survey. Furthermore, 6 interviewees, including scholars in the fields of circular economy, policy development, and recreational sports, consumers who volunteered to be interviewed, and a practitioner of the leisure industry, were invited to participate. The researchers first used a video system and telephone to obtain the interviewee's consent to be interviewed, and then used a semi-structured interview method to conduct the survey, in which they were asked to express their opinions on the analysis and results of the questionnaire. Finally, all the data were collected and analyzed using multiple comparison analysis testing.

However, due to the limitations of research funding, labor resources, and materials, and because of the ongoing COVID-19 pandemic, the environmental risks of the survey increased simultaneously. This limited the size of the samples and the number of sampling areas $[93,94]$, which may lead to differences in data analysis and results. These issues are 
noted in the recommendations of this study for future research, in the hope that subsequent researchers will remedy them.

\subsection{Ethical Considerations}

This survey undertaken study was conducted in Meizhou City, Guangdong Province, local consumers were the subjects, and a mixed research method was adopted. Although the analysis was conducted based on personal perception and cognition, to protect the privacy of the respondents and due to constraints such as time, labor resources, material resources, and funds used for questionnaire surveys and interviews, in addition to the wishes of the respondents, participants were interviewed anonymously. When the survey was conducted, the respondents were asked three times whether they were willing to be interviewed. Firstly, before the interview, the survey team gave a written or oral statement. Secondly, they asked for the respondent's willingness to answer the questions again during the questionnaire and interview. Finally, after the survey, they were asked about their willingness to authorize the survey data. Furthermore, all interviewees and respondents were scholars with expertise in circular economy, policy development, and leisure sports, or people with experience of using an e-bike sharing system. Therefore, the researchers believe that all interviewees and respondents had a certain degree of knowledge and experience of the research issues, and were familiar with the research topic and survey methods. In addition, the interviewees and respondents were willing to communicate information anonymously and assist in survey records and data collection. Therefore, because the research design and data collection were carried out based on rigorous standards, they complied with ethical norms [105-108].

\section{Analysis}

\subsection{Background Analysis}

A total of 800 questionnaires were returned for this study, and narrative statistics were used to analyze the respondents' background information. It was found that $62.5 \%$ of respondents were female and 37.5\% were male. The largest age group was under $20(48.8 \%)$, followed by the age groups of 21-30 (25.8\%), 31-40, and 41-50 (11.5\%), and the smallest was over $51(2.5 \%)$. The majority had university degrees $(76.8 \%)$, followed by those with junior high diplomas (12.3\%) and high school and vocational high school diplomas (8.5\%), and the smallest group had graduate degrees (2.5\%).

It can be seen that female college students under the age of 20 used the e-bike sharing system most, while men with graduate degrees aged over 51 used the e-bike sharing system least.

\subsection{Analysis of Amenities and Environmental Experience Value, Leisure Involvement, Leisure Satisfaction and Well-Being Cognition}

\subsubsection{Well-Being}

Well-being is a kind of cognition of the current emotions and preferences measured using personal subjective feelings [59,60]. Well-being can be defined as when the material needs of personal life are satisfied and the interaction with the atmosphere of the living environment surrounding people is recognized [59-61]. However, policy making usually has positive and negative effects [40,42], and there is significant difference in the wellbeing cognition between people with different backgrounds [83-87], as shown in Table 3. Therefore, in the narrative analysis of this study, the $t$-test, ANOVA, and other methods were used to verify whether there is a difference in people's cognition of well-being. This is Hypothesis 1.

The analysis results showed that "most like to engage in leisure in this way" (4.13), "feel relaxed" (4.13), and "helpful to make leisure planning" (4.09), were more widely perceived, whereas "have more opportunities to participate in leisure" (4.07), "be able to interact with others" (4.06), and "more active life" (3.98) were less widely perceived. There was a significant difference in "more active life" between genders $(p<0.01)$, and males 
had stronger feelings. There were significant differences in all of the issues of well-being between age groups and people with different education levels $(p<0.01)$. Among these groups, those aged 31-40 had the strongest feelings for "most like to engage in leisure in this way". Those with college degrees had the strongest feelings for "more active life". These results are inconsistent with Hypothesis 1.

It can be seen that using an e-bike sharing system helps the respondents to plan leisure activities and to relax physically and mentally, and that it is their favorite means of doing so. However, it does not particularly enhance the feelings about an active life, or increase opportunities for leisure participation and interaction with others. The results showed that not all people believed that e-bikes contribute to increased happiness, health, and well-being. Therefore, this result is inconsistent with that found in the literature [55,56].

It seems reasonable to infer that there are currently many companies operating e-bike sharing systems in China, and that there are a significant number of facilities. Coupled with the establishment of a mobile phone network system, this environment helps people to search for and operate e-bikes, and to make a choice more easily. Therefore, we believe that it is helpful to improve people's well-being.

However, most users would rather use electric energy to propel the e-bike than ride it, and there are many means of transportation for leisure activities. Moreover, people use the system on their own, and have few opportunities to communicate and interact with others. Therefore, although people believe that using an e-bike sharing system helps them to plan their leisure activities, and it is their favorite means to physically and mentally relax, it does not particularly enhance the feelings for an active life or increase their opportunities for leisure participation and interaction with others. Therefore, we believe that it does not help to improve people's well-being.

Among the respondents, men and those with college degrees had stronger feelings regarding an active life. The 31-40 age group thought they "most like this way" and that it was "helpful for people to make leisure planning". The results showed that people of different backgrounds, in terms of gender, age, and education, were unable to agree that e-bikes can help increase feelings of happiness and health. Therefore, this result is inconsistent with that found in the literature $[48,49]$.

It can be inferred that men go outside to participate in leisure activities more frequently compared to women, and that women are afraid of being exposed to the sun. In addition, there are many e-bike sharing systems from which users can choose for the purpose of energy-saving and reduction in carbon emissions. Therefore, males with college degrees had stronger feelings for an active life. The 31-40 age group thought they "like this way most" and that the system helps them to plan leisure activities. Therefore, we believe that these problems will cause a decline in the happiness of the 31-40 age group, most women, and men with university degrees. 
Table 3. Analysis of cognitive differences in well-being.

\begin{tabular}{|c|c|c|c|c|c|c|c|c|c|c|c|c|c|c|c|c|c|c|c|c|c|}
\hline \multirow[b]{2}{*}{ Facet } & \multirow[b]{2}{*}{ Subfactor } & \multirow[b]{2}{*}{ Issue } & \multirow[b]{2}{*}{ M } & \multirow[b]{2}{*}{ SD } & \multirow[b]{2}{*}{ Rank } & \multicolumn{3}{|c|}{ Gender } & \multicolumn{7}{|c|}{ Age } & \multicolumn{6}{|c|}{ Education Level } \\
\hline & & & & & & Male & Female & $p$-Value & $\begin{array}{l}\text { under } \\
20\end{array}$ & $21-30$ & $31-40$ & $41-50$ & $\begin{array}{c}\text { over } \\
51\end{array}$ & $p$-Value & Post Hoc & Junior & Senior & College & Graduate & $p$-Value & $\begin{array}{l}\text { Post } \\
\text { Hoc }\end{array}$ \\
\hline \multirow{6}{*}{ Well-being } & \multirow{2}{*}{$\begin{array}{l}\text { Life } \\
\text { satisfaction }\end{array}$} & \multirow{2}{*}{$\begin{array}{l}\text { Have more } \\
\text { opportunities to } \\
\text { participate in leisure } \\
\text { Convenient for leisure } \\
\text { planning }\end{array}$} & 4.07 & 0.803 & 2 & 4.06 & 4.07 & 0.825 & 4.25 & 3.87 & 4.00 & 2.50 & 3.50 & $0.000 *$ & N.A & 3.03 & 3.93 & 4.16 & 4.00 & $0.000 *$ & N.A \\
\hline & & & 4.09 & 0.790 & 1 & 4.05 & 4.10 & 0.187 & 4.23 & 3.90 & 4.50 & 3.00 & 3.80 & $0.000 *$ & $\begin{array}{c}31-40>\text { under } \\
20,21-30,41-50\end{array}$ & 3.28 & 4.00 & 4.16 & 4.00 & $0.000 *$ & N.A \\
\hline & \multirow{2}{*}{$\begin{array}{l}\text { Physical and } \\
\text { mental health }\end{array}$} & $\begin{array}{l}\text { Relaxation of body } \\
\text { and mind }\end{array}$ & 4.13 & 0.876 & 1 & 4.09 & 4.16 & 0.027 & 4.25 & 3.97 & 4.50 & 3.00 & 4.10 & $0.000 *$ & N.A & 3.24 & 4.00 & 4.20 & 4.40 & $0.000 *$ & N.A \\
\hline & & Life correction & 3.98 & 0.905 & 2 & 4.05 & 3.94 & $0.007 *$ & 4.23 & 3.64 & 4.50 & 2.50 & 3.80 & $0.000 *$ & N.A & 3.31 & 4.00 & 4.03 & 4.10 & $0.001 *$ & $\begin{array}{c}\text { college }>> \\
\text { junior }\end{array}$ \\
\hline & \multirow[t]{2}{*}{ Self-affirmation } & $\begin{array}{l}\text { I like to engage in } \\
\text { leisure in this way }\end{array}$ & 4.13 & 0.797 & 1 & 4.09 & 4.16 & 0.349 & 4.24 & 3.99 & 4.50 & 2.50 & 4.30 & $0.000 *$ & $\begin{array}{c}31-40>\text { under } \\
20,21-30,41-50 \\
\text { over } 51\end{array}$ & 3.62 & 4.00 & 4.16 & 4.70 & $0.000^{*}$ & N.A \\
\hline & & $\begin{array}{l}\text { Able to interact with } \\
\text { others }\end{array}$ & 4.06 & 0.842 & 2 & 4.06 & 4.05 & 0.041 & 4.23 & 3.84 & 4.00 & 3.00 & 3.80 & $0.000 *$ & N.A & 3.34 & 4.00 & 4.11 & 4.40 & $0.000 *$ & N.A \\
\hline
\end{tabular}




\subsubsection{Amenities and Environmental Experience Value}

Amenities experience value is the customer's cognition of the product evaluation of the physical and psychological satisfaction of the experience gained from the amenities and their surrounding environment [65], compared with the past experience [66,67]. However, policy making usually has positive and negative effects [40,42], and people with different backgrounds have a different experience cognition of the same facility [72]. Therefore, studies suggest that there will be differences in people's experience value cognition of the e-bike sharing system amenities and the surrounding environment. In the narrative analysis of this study, the $t$-test, ANOVA, and other methods were therefore used to analyze whether there is a difference in people's experience value cognition of e-bike sharing system amenities and the surrounding environment. This is Hypothesis 2.

The analysis results showed that an enjoyable consumption experience and fondness for other products (4.05), clear information (4.08), and detailed description (4.07)were more widely perceived, whereas representing personal characteristics (3.74), clear guide function (3.95), and high cost performance ratio (4.01) were less widely perceived. There was no significant difference between genders $(p>0.01)$, and there were significant differences between different age groups and people with different education levels $(p<0.01)$, as shown in Table 4. Among these groups, those under the age of 20 had the strongest feelings for high cost performance ratio and improving social identity, whereas the age group of 31-40 had the strongest feelings for representing personal characteristics, detailed description, right choice, happy consumer experience, and fondness for other products. By comparison, people with college degrees had strongest feelings for ride comfort, high cost performance ratio, and right choice, whereas people with graduate degrees had strongest feelings for clear guide function, reliable information, pleasant consumer experience, fondness for other products, enhancing social identity, and representing personal characteristics. The results are inconsistent with Hypothesis 2.

It can be seen that people believed that information related to the e-bike sharing system-related was clear, they had a pleasant consumption experience, and users were more willing to consume other goods. However, the guide function needed to be improved, the rental fee should be lowered, and the use of e-bike sharing system did not represent personal characteristics. The results show that not all people have a positive perception of the value of their e-bike experience. Therefore, this result is inconsistent with that found in the literature [60-65].

It seems reasonable to infer that, because we are in an era of $5 \mathrm{G}$ communication and smooth network searching, companies are seeking breakthroughs regarding fair competition, gradually improving the software and hardware planning of the e-bike sharing system, and setting up a large number of e-bike docks. Thus, users have had good consumer experiences. Therefore, we believe that these will increase happiness.

However, due to the popularization of the facilities, the rental fee is charged based on the rental time, and users need to pay a minimum rental fee. In addition, mobile phones can only be used to inquire about one operator's e-bike sharing system, and not about those of other operators. Therefore, people think that, although the information about the e-bike sharing system is clear and the consumer experience is pleasant, thus encouraging them to consume other products, the use of the system does not represent personal characteristics because the facilities have been popularized, the guide function needs to be improved, and the price should be lowered. Therefore, we believe that, due to these problems, people's happiness will not be improved.

After analyzing the feelings of different backgrounds, we found that consumers under the age of 20 believed that using an e-bike sharing system can increase their sense of social identity and the cost performance was high. By comparison, the 31-40 age group believed that, because of the detailed description, they had a pleasant consumer experience, and therefore felt that they had made the right choice and were willing to try other products. This age group also thought the system could represent personal characteristics. 
Respondents with college degrees experienced the ride comfort and felt that the cost performance ratio was high when using the e-bike sharing system, so they thought the choices they made were correct. Respondents with graduate degrees thought that because the guide function was clear and the information was reliable, they had a pleasant consumer experience, were willing to consume other products, and thought that the use of an e-bike sharing system could enhance social identity and represent personal characteristics. The results indicated that the value of the e-bike experience was not perceived positively by people of all ages and educational backgrounds. Therefore, this result is inconsistent with that found in the literature [65].

It can be inferred that the e-bike sharing system is already a popular means of public transportation in China. For young consumers, making a short-distance trip is convenient, the cost is within a reasonable range, and the willingness to use it is high. Moreover, using a mobile phone to inquire about an e-bike sharing system is fast. In addition, the failure reporting and service is also fast. Thus, the studied system is currently the most convenient and safe public transportation system. Therefore, consumers under the age of 20 thought that the use of an e-bike sharing system can increase their sense of social identity and that the cost performance ratio is high. Consumers in the 31-40 age group believed that because of the detailed description, they had pleasant consumer experiences, and therefore felt that they made the right choice and were willing to consume other products. They also felt the system could represent personal characteristics. Therefore, we believe that this will allow people younger than 20 and those aged 31-40 to be more able to recognize the benefits and contributions of e-bikes.

Finally, highly educated people are usually more knowledgeable about technology, have more opportunities to use networks for information exchange and consumption, and tend to be environmentalists. Therefore, respondents with college degrees experienced the ride comfort and felt that the cost performance ratio was high when using the e-bike sharing system; thus, they thought the choices they made were correct. Respondents with graduate degrees thought that because the guide function was clear and the information was reliable, they had a pleasant consumer experience, were willing to consume other products, and thought that the use of the e-bike sharing system could enhance social identity and represent personal characteristics. Therefore, we believe this will allow people with degrees in higher education to better appreciate the personal benefits and social contributions resulting from the promotion of e-bikes.

\subsubsection{Leisure Involvement}

Leisure involvement refers to the continual involvement and participation in a certain activity that the individual feels is important, mainly due to personal needs, interests, and viewpoints $[75,76]$. However, policy making usually has positive and negative effects $[40,42]$, and people with different backgrounds have different experience cognition of the same facility [80-85]. Therefore, studies suggest that there will be differences in people's leisure involvement cognition. In the narrative analysis of this study, the $t$-test, ANOVA, and other methods were used to verify whether there is a difference in people's leisure involvement cognition. This is Hypothesis 3.

The analysis results showed that "very satisfying and interesting" (4.08), "like to use the tool to engage in leisure" (4.11), and "normal and natural behavior" (4.03) were more widely perceived, whereas "can express their own characteristics" (3.90), "life accounts for a large part" (3.89), and "very Important daily habits" (3.99) were less widely perceived. There were significant differences in the ability of different genders to express their own characteristics, and males expressed stronger feelings. There was a significant difference in leisure involvement between age groups $(p<0.01)$, as shown in Table 5. Although there was no significant difference in "like to use the tool to engage in leisure" between respondents with different educational levels $(p>0.01)$, there were significant differences in all of the other issues $(p<0.01)$. Among these groups, people over 51 had the most significant cognition of the issue of "able to express their own characteristics". Respondents 
with graduate degrees had the strongest feelings regarding the issue of "very important". The results are inconsistent with Hypothesis 3.

It can be seen that people believe that using an e-bike sharing system to participate in leisure activities is a daily choice, and are satisfied with and interested in the system. However, the e-bike sharing system is not the main means of travel or an important choice in people's daily lives and leisure activities, nor can it highlight their own characteristics. The results showed that not all people had sufficient recreational participation opportunities through e-bikes or achieved a positive perception of recreational participation. Therefore, this result is inconsistent with that found in the literature [67-69,72-77].

It seems reasonable to infer, because many companies are operating e-bike sharing systems in China, and a number of options available, that this system is relatively convenient for people's daily life and leisure. It can be seen that the increase in the number of shared e-bike industries and facilities will help provide people with more energy-efficient transportation options and reduce inconvenience in their lives. Therefore, we believe that this will help to increase people's happiness.

However, because of the large range of opportunities for leisure or consumption, there is a range of distances to travel to take part in these activities. Furthermore, people can choose from bike share systems, taxis, and public buses. Therefore, these issues will reduce people's dependence on e-bikes and their related happiness.

As a result, people think that, although using e-bike sharing system to participate in leisure activities is a daily choice, and they are satisfied with and interested in the system, the use of e-bike sharing system is not the main means of travel or an important choice in people's daily life and leisure activities. Nor can it highlight their own characteristics. Therefore, we believe that these problems will affect people's happiness.

After analyzing the feelings of different backgrounds, we found that men over 51 years thought that using an e-bike sharing system could express their own characteristics. Those with graduate degrees thought that the use of e-bike sharing system was a very important action. The results showed that not all people of different backgrounds, such as in terms of age and education, had sufficient opportunities to participate in leisure activities through e-bikes and had a positive perception of leisure participation. Therefore, this result is inconsistent with that found in the literature [68-70].

Furthermore, women do not want to be overexposed to the sun. For senior citizens, access to and use of an e-bike sharing system is currently a symbol of technology and technique. In addition, when people go outside for leisure activities or consumption, the e-bike sharing system is a public transportation vehicle with a low risk of infection during the COVID-19 pandemic. Thus, among the respondents, men over 51 years old thought that using an e-bike sharing system could express their own characteristics, and those with graduate degrees thought that the use of an e-bike sharing system was a very important action. Therefore, we believe that these problems will affect the happiness of women, men over 51, and people with master's degrees or higher when they use e-bikes to engage in leisure activities.

\subsubsection{Leisure Satisfaction}

Leisure satisfaction means that when an individual's experience of the actual leisure environment or activities meets personal expectations, he/she will be satisfied; otherwise, he/she will be dissatisfied [82]. However, policy making usually has positive and negative effects $[40,42]$, and there is a significant difference in the leisure satisfaction cognition between people with different backgrounds [83-87]. Therefore, in the narrative analysis of this study, the $t$-test, ANOVA, and other methods were used to verify whether there is a difference in people's leisure satisfaction cognition. This is Hypothesis 4.

The analysis results showed that "like to engage in activities" (3.76), "regain vigor" (3.88), "learn new things from others" (3.90), "develop friendly relationships" (3.97), "can stabilize my emotions" (3.75), and "open and safe" (3.84) were more widely perceived, whereas "well-planned" (3.79), "let me feel relaxed" (3.65), "make friends" (3.91), "broaden 
my knowledge" (3.76), "physically challenged" (3.86), and "engaging in activities is important" (3.69) were less widely perceived. There were no significant differences in leisure satisfaction between genders, age groups, or people with different educational levels $(p>0.01)$. These results are inconsistent with Hypothesis 4 .

It can be seen that people believe that using the e-bike sharing system to participate in leisure activities is an open and safe choice, which can help them stabilize emotions, regain vigor, learn about new things, and develop friendly relationships. However, the system is currently not well planned, and does not help users to broaden their knowledge, make friends, improve their physical fitness, or gain the benefits of exercise. The results indicated that not all people were able to obtain positive leisure satisfaction perceptions while engaging in leisure activities via e-bikes. Therefore, this result is inconsistent with that found in the literature [67-69,72-77].

It seems reasonable to infer that e-bike sharing systems are used by individuals in an open space, which reduces the risk of contact with others. In addition, the riding modes of an e-bike can be changed to use either the motor or the rider's power; thus, the rider can undertake exercise by pedaling, or use electricity to propel the bike in a timely manner. Therefore, the e-bike is a vehicle that is convenient to operate and can help people undertake exercise. As a result, we believe that this system helps provide people with health benefits and happiness.

However, most users would rather use electric energy to propel the e-bike than pedal it themselves. In addition, the network operation interface and system are mainly used for e-bike rental, and no other services are provided in the system. Therefore, people believe that using an e-bike sharing system to participate in leisure activities is an open and safe choice, which can help them stabilize emotions, regain vigor, learn new things, and develop friendly relationships. However, the system is currently not well planned, and does not help users to broaden their knowledge, make friends, improve their physical fitness, or gain the benefits of exercise. Therefore, we believe that, due to these problems, people's happiness will not be improved.

After continuing to analyze the feelings of different backgrounds, we found that there few differences in the opinions of those having different genders, ages, and educational backgrounds. The results showed that all people agreed that engaging in leisure activities through e-bikes had a certain influence on their perception of personal leisure satisfaction. Therefore, this result is consistent with that found in the literature [67-69,72-77].

It is reasonable to infer that although e-bikes can be used for exercise, pedaling an e-bike is slow and has poor efficiency. Therefore, most people are using e-bikes during the pandemic for short-distance travel, mainly because it is easy to locate, borrow, and ride a shared e-bike for personal use, rather than because of its additional functions (that is, leisure and tourism functions). Therefore, after analyzing the feelings of different backgrounds, we found that there was little difference in the opinions of those having different genders, ages, and educational backgrounds. As a result, we believe that most people do not think that using e-bikes for leisure activities will provide them with much happiness.

\subsection{Correlation Analysis of Experience Value, Leisure Involvement, Leisure Satisfaction and Well-Being Cognition}

Policies are implemented to address local development challenges, improve the local economic and environmental status, and upgrade people's quality of life [40-42]. The government has developed transportation policies such as e-bike sharing systems to achieve a carbon reduction, establish a convenient and friendly environment, and create a leisure and tourism atmosphere [40], as shown in Table 6. This will help increase people's willingness to plan for leisure. Research has confirmed that a positive experience value, leisure involvement, and satisfaction cognition can help improve people's feelings of happiness and well-being, and help build a healthy and happy city [36]. These observations are the bases of Hypotheses 5-7. 
Table 4. Analysis of cognitive differences in environmental experience value, leisure involvement, leisure satisfaction, and well-being.

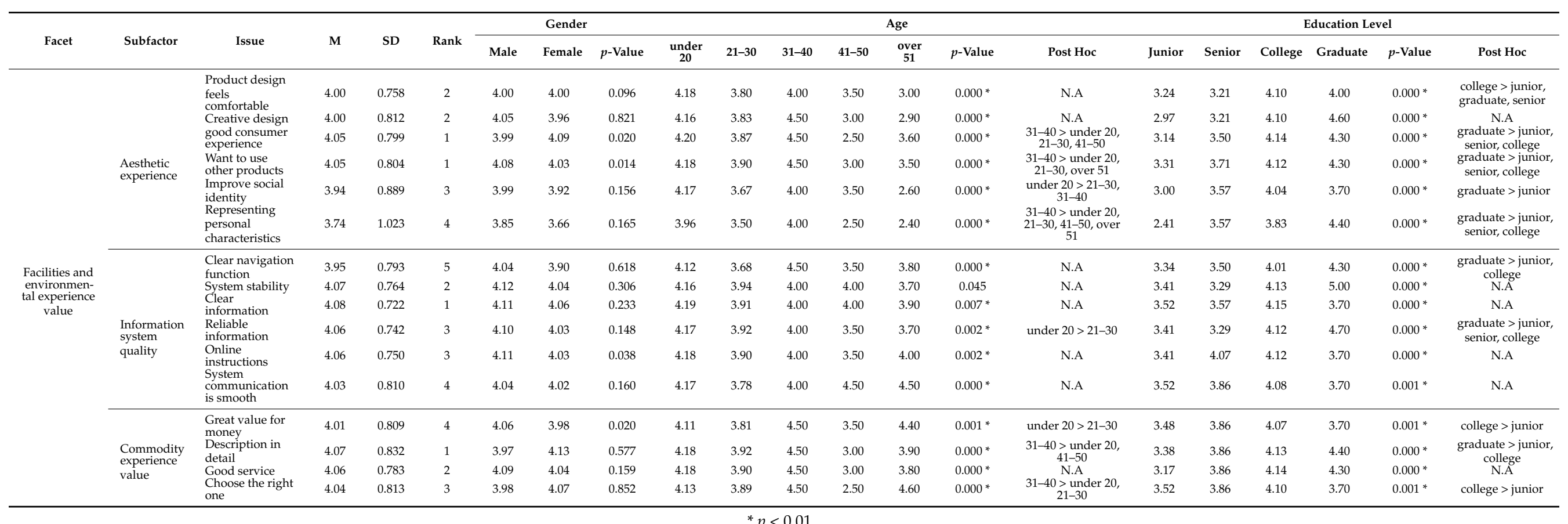


Table 5. Analysis of cognitive differences in leisure involvement.

\begin{tabular}{|c|c|c|c|c|c|c|c|c|c|c|c|c|c|c|c|c|c|c|c|c|c|}
\hline \multirow[b]{2}{*}{ Facet } & \multirow[b]{2}{*}{ Subfactor } & \multirow[b]{2}{*}{ Issue } & \multirow[b]{2}{*}{$\mathbf{M}$} & \multirow[b]{2}{*}{ SD } & \multirow[b]{2}{*}{ Rank } & \multicolumn{3}{|c|}{ Gender } & \multicolumn{7}{|c|}{ Age } & \multicolumn{6}{|c|}{ Education Level } \\
\hline & & & & & & Male & Female & $p$-Value & $\begin{array}{c}\text { under } \\
20\end{array}$ & $21-30$ & $31-40$ & $41-50$ & $\begin{array}{c}\text { over } \\
51\end{array}$ & $p$-Value & Post Hoc & Junior & Senior & College & Graduate & $p$-Value & Post Hoc \\
\hline \multirow{9}{*}{$\begin{array}{l}\text { Leisure } \\
\text { involvement }\end{array}$} & \multirow{2}{*}{ Attractiveness } & \multirow{2}{*}{$\begin{array}{l}\text { Important } \\
\text { dependence } \\
\text { Very satisfying and } \\
\text { interesting }\end{array}$} & 3.99 & 0.901 & 2 & 4.10 & 3.92 & 0.125 & 4.16 & 3.71 & 5.00 & 2.50 & 4.20 & $0.000 *$ & N.A & 3.48 & 3.71 & 4.03 & 4.60 & $0.001 *$ & $\begin{array}{l}\text { graduate }>\text { junior } \\
\text { college }\end{array}$ \\
\hline & & & 4.08 & 0.819 & 1 & 4.12 & 4.06 & 0.123 & 4.22 & 3.82 & 5.00 & 4.00 & 4.10 & $0.000 *$ & N.A & 3.79 & 3.43 & 4.13 & 4.10 & $0.003 *$ & college $>$ senior \\
\hline & \multirow{4}{*}{ Centrality } & \multirow{4}{*}{$\begin{array}{l}\text { Like to use this tool } \\
\text { for leisure } \\
\text { Life is a big part } \\
\text { play an important } \\
\text { role } \\
\text { Discuss chat topics }\end{array}$} & 4.11 & 0.819 & 1 & 4.11 & 4.10 & 0.878 & 4.22 & 3.87 & 5.00 & 3.50 & 4.50 & 0.000 * & N.A & 3.72 & 4.00 & 4.14 & 4.00 & 0.058 & N.A \\
\hline & & & 3.89 & 0.990 & 4 & 4.04 & 3.79 & 0.018 & 4.13 & 3.50 & 5.00 & 3.00 & 3.50 & 0.000 * & N.A & 3.00 & 4.21 & 3.93 & 4.30 & $0.000 *$ & N.A \\
\hline & & & 3.96 & 0.918 & 3 & 4.07 & 3.90 & 0.026 & 4.15 & 3.65 & 4.50 & 3.00 & 4.20 & $0.000 *$ & N.A & 3.24 & 4.21 & 4.01 & 4.00 & $0.000 *$ & N.A \\
\hline & & & 4.02 & 0.926 & 2 & 4.05 & 4.00 & 0.029 & 4.18 & 3.76 & 4.50 & 2.50 & 4.60 & $0.000 *$ & N.A & 3.76 & 4.50 & 4.04 & 3.40 & 0.013 & N.A \\
\hline & \multirow{3}{*}{ Self-expression } & $\begin{array}{l}\text { Friends also choose } \\
\text { the same product }\end{array}$ & 4.00 & 0.946 & 2 & 4.01 & 4.00 & 0.347 & 4.22 & 3.71 & 4.00 & 2.50 & 4.00 & $0.000 *$ & $\begin{array}{c}\text { N.A } \\
\text { over } 51>\end{array}$ & 2.83 & 3.79 & 4.09 & 4.70 & $0.000 *$ & N.A \\
\hline & & $\begin{array}{l}\text { Can express one's } \\
\text { own characteristics }\end{array}$ & 3.90 & 0.901 & 3 & 4.02 & 3.83 & $0.005 *$ & 4.11 & 3.55 & 4.50 & 2.50 & 4.50 & $0.000 *$ & $\begin{array}{l}\text { under 20, } \\
21-30, \\
31-40, \\
41-50\end{array}$ & 3.41 & 4.07 & 3.96 & 3.10 & $0.000 *$ & N.A \\
\hline & & $\begin{array}{l}\text { Normal and } \\
\text { natural behavior }\end{array}$ & 4.03 & 0.852 & 1 & 4.05 & 4.02 & 0.820 & 4.17 & 3.88 & 4.50 & 2.50 & 3.50 & $0.000 *$ & N.A & 2.86 & 3.79 & 4.13 & 4.40 & $0.000 *$ & N.A \\
\hline
\end{tabular}

Table 6. Analysis of cognitive differences in leisure satisfaction.

\begin{tabular}{|c|c|c|c|c|c|c|c|c|c|c|c|c|c|c|c|c|c|c|c|c|c|}
\hline \multirow{2}{*}{ Facet } & \multirow{2}{*}{ Subfactor } & \multirow{2}{*}{ Issue } & \multirow{2}{*}{$\mathbf{M}$} & \multirow{2}{*}{ SD } & \multirow{2}{*}{ Rank } & \multicolumn{3}{|c|}{ Gender } & \multicolumn{7}{|c|}{ Age } & \multicolumn{6}{|c|}{ Education Level } \\
\hline & & & & & & Male & Female & $p$-Value & under 20 & $21-30$ & $31-40$ & $41-50$ & over 51 & $p$-Value & Post Hoc & Junior & Senior & College & Graduate & $p$-Value & Post Hoc \\
\hline \multirow{5}{*}{$\begin{array}{l}\text { Leisure } \\
\text { satisfaction }\end{array}$} & Physiological & $\begin{array}{l}\text { Heavy activity } \\
\text { Like to engage in activities }\end{array}$ & $\begin{array}{l}3.69 \\
3.76\end{array}$ & $\begin{array}{l}1.171 \\
1.140\end{array}$ & $\begin{array}{l}2 \\
1\end{array}$ & $\begin{array}{l}3.67 \\
3.79\end{array}$ & $\begin{array}{l}3.70 \\
3.74\end{array}$ & $\begin{array}{l}0.630 \\
0.609\end{array}$ & $\begin{array}{l}3.68 \\
3.79\end{array}$ & $\begin{array}{l}3.71 \\
3.73\end{array}$ & $\begin{array}{l}4.17 \\
4.33\end{array}$ & $\begin{array}{l}3.33 \\
3.17\end{array}$ & $\begin{array}{l}3.70 \\
3.60\end{array}$ & $\begin{array}{l}0.809 \\
0.459\end{array}$ & $\begin{array}{l}\text { N.A } \\
\text { N.A }\end{array}$ & $\begin{array}{l}3.59 \\
3.69\end{array}$ & $\begin{array}{l}4.07 \\
3.79\end{array}$ & $\begin{array}{l}3.69 \\
3.78\end{array}$ & $\begin{array}{l}3.50 \\
3.50\end{array}$ & $\begin{array}{l}0.579 \\
0.875\end{array}$ & $\begin{array}{l}\text { N.A } \\
\text { N.A }\end{array}$ \\
\hline & Psychological & $\begin{array}{l}\text { Physical fitness is challenging } \\
\text { Physical recovery }\end{array}$ & $\begin{array}{l}3.86 \\
3.88\end{array}$ & $\begin{array}{l}1.111 \\
1.075\end{array}$ & ${ }_{1}^{2}$ & $\begin{array}{l}3.85 \\
3.84\end{array}$ & $\begin{array}{l}3.86 \\
3.91\end{array}$ & $\begin{array}{l}0.864 \\
0.914\end{array}$ & $\begin{array}{l}3.90 \\
3.80\end{array}$ & $\begin{array}{l}3.81 \\
3.99\end{array}$ & $\begin{array}{l}4.17 \\
4.50\end{array}$ & $\begin{array}{l}3.17 \\
3.33\end{array}$ & $\begin{array}{l}3.90 \\
4.10\end{array}$ & $\begin{array}{l}0.502 \\
0.152\end{array}$ & $\begin{array}{l}\text { N.A } \\
\text { N.A }\end{array}$ & $\begin{array}{l}3.79 \\
3.97\end{array}$ & $\begin{array}{l}4.14 \\
4.14\end{array}$ & $\begin{array}{l}3.87 \\
3.87\end{array}$ & $\begin{array}{l}3.40 \\
3.80\end{array}$ & $\begin{array}{l}0.434 \\
0.774\end{array}$ & $\begin{array}{l}\text { N.A } \\
\text { N.A }\end{array}$ \\
\hline & Educational & $\begin{array}{l}\text { Broaden horizons } \\
\text { Learn new things through others }\end{array}$ & $\begin{array}{l}3.76 \\
3.90\end{array}$ & $\begin{array}{l}1.020 \\
1.098\end{array}$ & $\begin{array}{l}2 \\
1\end{array}$ & $\begin{array}{l}3.82 \\
3.95\end{array}$ & $\begin{array}{l}3.72 \\
3.88\end{array}$ & $\begin{array}{l}0.321 \\
0.120\end{array}$ & $\begin{array}{l}3.74 \\
3.87\end{array}$ & $\begin{array}{l}3.77 \\
3.95\end{array}$ & $\begin{array}{l}4.50 \\
4.50\end{array}$ & $\begin{array}{l}3.67 \\
3.50\end{array}$ & $\begin{array}{l}3.60 \\
3.90\end{array}$ & $\begin{array}{l}0.476 \\
0.544\end{array}$ & $\begin{array}{l}\text { N.A } \\
\text { N.A }\end{array}$ & $\begin{array}{l}3.79 \\
4.00\end{array}$ & $\begin{array}{l}3.86 \\
4.14\end{array}$ & $\begin{array}{l}3.76 \\
3.90\end{array}$ & $\begin{array}{l}3.60 \\
3.50\end{array}$ & $\begin{array}{l}0.940 \\
0.523\end{array}$ & $\begin{array}{l}\text { N.A } \\
\text { N.A }\end{array}$ \\
\hline & Social & $\begin{array}{l}\text { meet new friends } \\
\text { Develop friendly relations }\end{array}$ & $\begin{array}{l}3.91 \\
3.97\end{array}$ & $\begin{array}{l}1.152 \\
1.138 \\
\end{array}$ & $\begin{array}{l}2 \\
1\end{array}$ & $\begin{array}{l}3.87 \\
3.88\end{array}$ & $\begin{array}{l}3.93 \\
4.02 \\
\end{array}$ & $\begin{array}{l}0.287 \\
0.151\end{array}$ & $\begin{array}{l}3.95 \\
4.00\end{array}$ & $\begin{array}{l}3.78 \\
3.83\end{array}$ & $\begin{array}{l}4.17 \\
4.33\end{array}$ & $\begin{array}{l}4.50 \\
4.67\end{array}$ & $\begin{array}{l}4.10 \\
4.60\end{array}$ & $\begin{array}{l}0.380 \\
0.077\end{array}$ & $\begin{array}{l}\text { N.A } \\
\text { N.A }\end{array}$ & $\begin{array}{l}4.10 \\
4.24\end{array}$ & $\begin{array}{l}3.86 \\
4.21\end{array}$ & $\begin{array}{l}3.89 \\
3.93 \\
\end{array}$ & $\begin{array}{l}4.00 \\
4.00\end{array}$ & $\begin{array}{l}0.801 \\
0.450\end{array}$ & $\begin{array}{l}\text { N.A } \\
\text { N.A }\end{array}$ \\
\hline & Relax & $\begin{array}{l}\text { Make me feel relaxed } \\
\text { Can stabilize my mood }\end{array}$ & $\begin{array}{l}3.65 \\
3.75\end{array}$ & $\begin{array}{l}1.190 \\
1.137\end{array}$ & $\frac{2}{1}$ & $\begin{array}{l}3.61 \\
3.73\end{array}$ & $\begin{array}{l}3.68 \\
3.75\end{array}$ & $\begin{array}{l}0.913 \\
0.633\end{array}$ & $\begin{array}{l}3.66 \\
3.75\end{array}$ & $\begin{array}{l}3.62 \\
3.73\end{array}$ & $\begin{array}{l}4.50 \\
4.50\end{array}$ & $\begin{array}{l}3.17 \\
3.00\end{array}$ & $\begin{array}{l}3.60 \\
3.70\end{array}$ & $\begin{array}{l}0.384 \\
0.262\end{array}$ & $\begin{array}{l}\text { N.A } \\
\text { N.A }\end{array}$ & $\begin{array}{l}3.66 \\
3.66\end{array}$ & $\begin{array}{l}3.64 \\
3.71\end{array}$ & $\begin{array}{l}3.67 \\
3.76\end{array}$ & $\begin{array}{l}3.20 \\
3.60\end{array}$ & $\begin{array}{l}0.686 \\
0.941\end{array}$ & $\begin{array}{l}\text { N.A } \\
\text { N.A }\end{array}$ \\
\hline
\end{tabular}


The analysis results showed that experience value, leisure involvement, and well-being are positively significant $(p<0.01)$. Among them, the aesthetic experience of experience value has the greatest influence on life satisfaction (0.799), physical and mental health (0.751), and self-affirmation (0.764), and has the least influence on the quality of the information system. Leisure involvement has the greatest influence on self-expression and life satisfaction (0.877), physical and mental health (0.878), and self-affirmation (0.860), and has the least influence on attractiveness. However, the study found that leisure satisfaction and happiness are not significant $(p<0.01)$, as shown in Table 7 . As a result, Hypotheses 5 and 6 are valid, but Hypothesis 7 is not.

Table 7. Correlation analysis of environmental experience value, leisure involvement, leisure satisfaction, and well-being.

\begin{tabular}{|c|c|c|c|c|c|c|c|c|}
\hline & $\begin{array}{l}\text { Aesthetic } \\
\text { Experience }\end{array}$ & $\begin{array}{c}\text { Information } \\
\text { System } \\
\text { Quality }\end{array}$ & $\begin{array}{l}\text { Commodity } \\
\text { Experience } \\
\text { Value }\end{array}$ & $\begin{array}{c}\text { Facilities and } \\
\text { Environmen- } \\
\text { tal Experience } \\
\text { Value }\end{array}$ & Attractiveness & Centrality & $\begin{array}{c}\text { Self- } \\
\text { Expression }\end{array}$ & $\begin{array}{c}\text { Leisure } \\
\text { Involvement }\end{array}$ \\
\hline Life satisfaction & $0.799^{* *}$ & 0.728 ** & $0.773^{* *}$ & 0.803 ** & $0.778^{* *}$ & 0.850 ** & $0.877^{* *}$ & $0.886^{* *}$ \\
\hline $\begin{array}{l}\text { Physical and } \\
\text { mental health }\end{array}$ & $0.751^{* *}$ & $0.692^{* *}$ & $0.739 * *$ & $0.761 * *$ & $0.722 * *$ & $0.796^{* *}$ & $0.878^{* *}$ & $0.849 * *$ \\
\hline $\begin{array}{l}\text { Self-affirmation } \\
\text { Well-being }\end{array}$ & $\begin{array}{l}0.764^{* *} \\
0.809^{* *}\end{array}$ & $\begin{array}{l}0.710^{* *} \\
0.745^{* *}\end{array}$ & $\begin{array}{l}0.747^{* *} \\
0.789^{* *}\end{array}$ & $\begin{array}{l}0.775^{* *} \\
0.818^{* *}\end{array}$ & $\begin{array}{l}0.687^{* *} \\
0.764^{* *}\end{array}$ & $\begin{array}{l}0.814^{* *} \\
0.860^{* *}\end{array}$ & $\begin{array}{l}0.860^{* *} \\
0.915^{* *}\end{array}$ & $\begin{array}{l}0.842^{* *} \\
0.901\end{array}$ \\
\hline & Physiological & Psychological & Educational & Social & Relax & Aesthetics & \multicolumn{2}{|c|}{ Leisure satisfaction } \\
\hline Life satisfaction & 0.015 & -0.020 & 0.008 & 0.092 & -0.021 & 0.011 & \multicolumn{2}{|c|}{0.017} \\
\hline $\begin{array}{l}\text { Physical and } \\
\text { mental health }\end{array}$ & -0.020 & -0.051 & -0.029 & 0.041 & -0.052 & -0.016 & \multicolumn{2}{|c|}{-0.025} \\
\hline $\begin{array}{l}\text { Self-affirmation } \\
\text { Well-being }\end{array}$ & $\begin{array}{c}0.003 \\
-0.002\end{array}$ & $\begin{array}{l}-0.029 \\
-0.036\end{array}$ & $\begin{array}{c}0.006 \\
-0.006\end{array}$ & $\begin{array}{l}0.087 \\
0.076\end{array}$ & $\begin{array}{l}-0.047 \\
-0.043\end{array}$ & $\begin{array}{c}0.001 \\
-0.002\end{array}$ & \multicolumn{2}{|c|}{$\begin{array}{c}0.004 \\
-0.002\end{array}$} \\
\hline
\end{tabular}

It can be seen that there is a positive and significant relationship between experience value, leisure involvement, and well-being. Among these, the aesthetic experience in experience value had the greatest influence on life satisfaction and physical and mental health, and self-expression and leisure involvement had the greatest influence on selfaffirmation and well-being.

It seems reasonable to infer that, because many e-bike sharing systems are available, the system is convenient to operate and highly mobile, and helps users to participate in leisure activities and undertake consumption planning. In addition, e-bikes have a compact design and are easy to operate. Numerous e-bike sharing systems are available, and borrowing and returning an e-bike is highly convenient. Therefore, these systems help people to gain practical experience and have a feeling of happiness. This indicates there is a positive and significant relationship between experience value, leisure involvement, and well-being. Moreover, the aesthetic experience in experience value had the greatest influence on life satisfaction and physical and mental health, and self-expression and leisure involvement had the greatest influence on self-affirmation and well-being.

Furthermore, it is inefficient to ride an e-bike with the power off, and e-bikes are mainly used as a transportation tool, rather than as a vehicle to allow riders to participate in leisure and tourism activities. Therefore, people's leisure satisfaction does not help to increase their happiness when they use e-bikes to engage in leisure activities.

5. Analysis of the Positive Influence of E-Bike Sharing Systems on the Convenience of Urban Leisure and Tourism Activities and the Happiness Index of the People and the City

Researchers believe that we are in an era of 5G communication and smoother network searching, which has increased the convenience of using networks. However, due to excessive energy consumption and the risk of the COVID-19 pandemic, developing newgeneration urban public transportation vehicles to replace fuel-powered vehicles will be the main trend in the future. Mobile phones are used with the e-bike sharing system to connect to the Internet. In addition, the e-bikes are placed, borrowed, and returned in open spaces, where individuals using the system can avoid contact with others, thus reducing the risk of infection. As a result, e-bikes are highly suited for use during the current pandemic. 
A large number of relevant companies currently exist. Because these companies operate in an environment of fair competition, they have installed a sufficiently large number of e-bike docks, provided various preferential treatments to users, and undertaken software and hardware planning, providing many options for customers. In addition, because an e-bike has an integrated electric motor to assist propulsion, while retaining the ability to be pedaled by the rider, it also provides the benefits of leisure sports, tourism, consumption, and green energy. Therefore, the e-bike sharing system can help cities to establish a green transportation network, promote people's participation in leisure and tourism activities, and encourage individuals to physically and mentally relax. By inference, the use of e-bikes as a short-distance transportation tool can help people to resume normal life and leisure activities, and experience a feeling of happiness during the pandemic.

The advantages of the e-bike sharing system include that it may reduce the risk of infection, and its high mobility, leisure, sports, and tourism value. As a result, it is favored by the 31-40 age group and those over 51, men, and those with college or higher degrees. However, although e-bike sharing systems have become popular, the e-bike battery does not last long, so is the e-bike can only be used for short rides. In addition, the pedaling mode of the e-bike is inefficient and difficult to operate. Moreover, mobile phones can currently only be used to inquire about one operator's e-bike sharing system and product information, and not about other consumer, leisure, and travel services. Most users would also rather use electric energy to propel the e-bike, rather than ride it to undertake exercise. Finally, because the rental fee is charged based on the rental time, which is disadvantageous to short-distance users, other means of transportation are preferred. Therefore, people do not feel the e-bike sharing system makes a contribution to the development of the city, or feel that its convenience helps them to participate in leisure and tourism activities. As a result of all of the above problems, people may experience less happiness when using e-bikes for leisure and tourism activities.

Therefore, it is recommended that the companies operating e-bike sharing systems should classify e-bikes based on electric capacity and charge the rental fee based on mileage, to meet the needs of users. Secondly, all operators should jointly provide their information, thus allowing users to browse all of the websites and make a choice accordingly. The operators should also develop a software interface with functions to allow users to rent e-bikes and search for information related to consumption, leisure, and travel activities. Finally, operators should implement promotion plans to encourage users to cycle in a timely manner, thus reducing power consumption, and promote the benefits of leisure sports to their customers. In this manner, the contribution of the e-bike sharing system and public transportation policy to urban development will be effectively enhanced. This will make it more convenient to participate in leisure and tourism activities, and substantially increase the happiness index of the people and the city.

\section{Conclusions and Recommendations}

The use of e-bike sharing systems can help to reduce the risk of infection. In addition, the system is convenient and easy to use for leisure, sports, and tourism activities. Therefore, many people like to use these systems, and have consequently experienced a feeling of happiness. However, only a minority of people appreciates the guide function of the software interface of the systems, and the convenience they provide for information searching. As a result, most people do not use an e-bike sharing system for daily or leisure activities. Additional problems also exist, such as the online charging system, access to electricity, and the small number of query software interfaces that connect leisure and travel information. Moreover, most users would rather use electric energy to propel the e-bike than ride it without the use of electric power, thus removing its function as a device for leisure sports. As a result, a minority of people understands the advantages of e-bikes, and most do not use it for daily or leisure activities. Although e-bike sharing systems can help allow people resume a normal life, and restore the economy and social order, it cannot help provide a safe and happy environment for leisure and travel activities, effectively 
improve people's personal, physical, or mental health, help people experience a feeling of happiness, or create a healthy and happy city.

Therefore, the characteristics and functions of electric bicycles can be effectively improved by expanding and enhancing the guide function of the systems' software interface; improving search convenience, the online charging system, and the interface that connects leisure and travel information; addressing power shortages; and increasing the pedaling power to enhance the effect of leisure sports. These measures will allow people to experience the feelings of health and happiness, and create a safe and friendly living environment, in addition to a happy city.

Based on the above analysis results and research limitations, the researchers propose the following recommendations:

\subsection{For Governments and Policymakers}

Combine all corporate information and make it available for people to search; implement promotion plans to encourage users to cycle in a timely manner and help people gain leisure and exercise benefits; and promote the benefits of leisure sports.

\subsection{For Enterprises and Hardware and Software Devices}

Develop a software interface having functions to rent e-bikes and search for information about consumption, leisure, and tourism activities; classify e-bikes based on electric capacity; charge the rental fee based on mileage, to meet the needs of users; and improve the driving efficiency of e-bike pedals.

\subsection{Recommendations for Future Research}

This study aimed to examine people's degree of happiness after they used the e-bike sharing system in Meizhou City, and the system's contribution to the city. In reality, other similar transportation systems can be used. Furthermore, this study found that there are shortcomings in the electric capacity of e-bikes; the information connection between consumption, leisure, and tourism activities; and the pedal assist system. Other issues can also be discussed. Therefore, it is recommended that future researchers use the theories and research framework of this study to carry out research in other countries and regions, or carry out follow-up studies to enable further discussion and verification.

Author Contributions: Conceptualization, H.-H.L.; methodology, H.-H.L. and C.-C.S.; software, H.-H.L. and C.-C.S.; validation, H.-H.L. and C.-C.S.; formal analysis, H.-H.L.; investigation, H.-H.L.; resources, C.-C.S., I.-C.H. and P.-Y.W.; data curation, H.-H.L.; writing-original draft preparation, I.-C.H.; writing-review and editing, P.-Y.W.; visualization, H.-H.L.; supervision, H.-H.L.; project administration, H.-H.L. All authors have read and agreed to the published version of the manuscript.

Funding: This research received no external funding.

Institutional Review Board Statement: At the beginning of the research, all subjects were invited to participate in the research explanatory meeting, answered questions on the spot, and confirmed the subjects' understanding of the subject and research questions. During the formal interview, the researcher again asked and confirmed the willingness to be interviewed, and collected several questionnaires. Therefore, the collection of research data goes through a rigorous process and conforms to ethical and ethical standards.

Informed Consent Statement: All subjects were involved in the research period, after the investigator conducted two questions and confirmations.

Data Availability Statement: No data support.

Conflicts of Interest: The authors declare no conflict of interest. 


\section{References}

1. Macke, J.; Casagrande, R.M.; Sarate, J.A.R.; Silva, K.A. Smart city and quality of life: Citizens' perception in a Brazilian case study. J. Clean. Prod. 2018, 182, 717-726. [CrossRef]

2. Senge, P. The necessary revolution. Lead. Lead. 2009, 51, 24-28. [CrossRef]

3. Frisch, M.B. Improving mental and physical health care through Quality of Life Therapy and assessment. In Advances in Quality of Life Theory and Research; Social Indicators Research Series; Diener, E., Rahtz, D.R., Eds.; Springer: Dordrecht, The Netherlands, 2000; Volume 4. [CrossRef]

4. Doppelt, B. Leading Change toward Sustainability: A Change-Management Guide for Business, Government and Civil Society; Routledge: London, UK, 2010.

5. Ghosh, M. (Ed.) Built Environment in Response to the Ecology, Design, and Perception of the Global South. In Perception, Design and Ecology of the Built Environment; Springer: Cham, Switzerland, 2010. [CrossRef]

6. Dharfizi, A.D.-H. The Energy Sector and the Internet of Things-Sustainable Consumption and Enhanced Security through Industrial Revolution 4.0. J. Int. Stud. 2018, 14, 99-117. [CrossRef]

7. Elliott, A. The Culture of AI: Everyday Life and the Digital Revolution; Routledge: London, UK, 2019.

8. Banister, D.; Berechman, Y. Transport investment and the promotion of economic growth. J. Transp. Geogr. 2001, 9, 209-218. [CrossRef]

9. Wang, L.; Xue, X.; Zhao, Z.; Wang, Z. The impacts of transportation infrastructure on sustainable development: Emerging trends and challenges. Int. J. Environ. Res. Public Health 2018, 15, 1172. [CrossRef] [PubMed]

10. Mannan, M.; Al-Ghamdi, S.G. Environmental impact of water-use in buildings: Latest developments from a life-cycle assessment perspective. J. Environ. Manag. 2020, 261, 110198. [CrossRef]

11. Guo, X.; Lü, X. The need for biofuels in the context of energy consumption. In Advances in 2nd Generation of Bioethanol Production; Elsevier: Xianyang, China, 2021; pp. 9-30. [CrossRef]

12. Brown, D. Climate Change: How Important Is China's Policy Response to the World. 2021. Available online: https://www.bbc com/zhongwen/trad/58146804 (accessed on 10 November 2021).

13. Global Carbon Project. Data Supplement to the Global Carbon Budget 2020. Available online: https://www.icos-cp.eu/scienceand-impact/global-carbon-budget/2020 (accessed on 10 November 2021).

14. The People's Republic of China. China's Policy and Action Plan to Address Climate Change. State Council of China, China. 2020 Available online: https://carnegieendowment.org/files/China_Climate_Change_Policies_Actions_Chinese.pdf (accessed on 10 November 2021).

15. Carbon Brief. Which Countries Are Historically Responsible for Climate Change? 2020. Available online: https://www.youtube. com/watch?v=6zP0L69ielU (accessed on 10 November 2021).

16. UN. Secretary-General. Oceans and the Law of the Sea: Report of the Secretary-General. 2020. Available online: https: / / digitallibrary.un.org/record/437569 (accessed on 21 September 2021).

17. UN. Secretary-General. Oceans and the Law of the Sea in the General Assembly of the United Nations. 2021. Available online: https://www.un.org/depts/los/general_assembly/general_assembly_reports.htm (accessed on 21 September 2021).

18. Baarsch, F.; Granadillos, J.R.; Hare, W.; Knaus, M.; Krapp, M.; Schaeffer, M.; Lotze-Campen, H. The impact of climate change on incomes and convergence in Africa. World Dev. 2020, 126, 104699. [CrossRef]

19. Lomborg, B. Welfare in the 21st century: Increasing development, reducing inequality, the impact of climate change, and the cost of climate policies. Technol. Forecast. Soc. Chang. 2021, 156, 119981. [CrossRef]

20. Pour, S.H.; Wahab, A.K.A.; Shahid, S.; Asaduzzaman, M.; Dewane, A. Low impact development techniques to mitigate the impacts of climate-change-induced urban floods: Current trends, issues and challenges. Sustain. Cities Soc. 2020, 62, 102373. [CrossRef]

21. Mei, H.; Li, Y.P.; Suo, C.; Ma, Y.; Lv, J. Analyzing the impact of climate change on energy-economy-carbon nexus system in China. Appl. Energy 2020, 262, 114568. [CrossRef]

22. Balat, M. Potential importance of hydrogen as a future solution to environmental and transportation problems. Int. J. Hydrogen Energy 2008, 33, 4013-4029. [CrossRef]

23. Meizhou City Government. Meizhou Cityscape. 2021. Available online: https://web.archive.org/web/20090514031915/http: //www.meizhou.gov.cn/mzgk/mzfm/2008-04-21/1208772436d20253.html (accessed on 13 November 2021).

24. Meizhou City Ecological Environment Bureau Wuhua Branch. Guangdong Low-Carbon Pilot Project Has Exceeded the Carbon Intensity Target for Ten Years, with a Cumulative Decrease of over $44 \%$. The Cumulative Turnover of Carbon Emission Quotas is 3.489 Billion Yuan. 2021. Available online: https://www.wuhua.gov.cn/mzwhhbj/gkmlpt/content/2/2113/post_2113477.html\# 18570 (accessed on 13 November 2021).

25. Meizhou Municipal Bureau of Statistics. Bulletin of the Seventh National Census of Meizhou City; China Statistics Press: Meizhou, China, 2021.

26. Meizhou Municipal Bureau of Statistics. Meizhou Municipal People's Government Network-A Brief Analysis of the Economic Performance of Meizhou in 2018. Available online: http://www.gd.gov.cn/zwgk/sjfb/dssj/content/post_160840.html (accessed on 13 November 2021).

27. Omer, A.M. Energy, environment and sustainable development. Renew. Sustain. Energy Rev. 2008, 12, 2265-2300. [CrossRef] 
28. Liu, R.; Pu, L.; Zhu, M.; Huang, S.; Jiang, Y. Coastal resource-environmental carrying capacity assessment: A comprehensive and trade-off analysis of the case study in Jiangsu coastal zone, eastern China. Ocean Coast. Manag. 2020, 186, 105092. [CrossRef]

29. Wolsink, M. Planning of renewables schemes: Deliberative and fair decision-making on landscape issues instead of reproachful accusations of non-cooperation. Energy Policy 2007, 35, 2692-2704. [CrossRef]

30. Eckert, E.; Kovalevska, O. Sustainability in the European Union: Analyzing the Discourse of the European Green Deal. J. Risk Financ. Manag. 2021, 14, 80. [CrossRef]

31. National Health Service Commission of the PRC. The Latest Situation of the New Coronavirus Pneumonia Epidemic at 24 O'clock on 8 April 2020. Available online: http:/ / www.nhc.gov.cn/xcs/yqtb/list_gzbd.shtml (accessed on 21 September 2021).

32. WHO. WHO Coronavirus Disease (COVID-19). 2020. Available online: https:/ / covid19.who.int/ (accessed on 21 September 2021).

33. Hsu, C.H.; Lin, H.H.; Wang, C.C.; Jhang, S.W. How to Defend COVID-19 in Taiwan? Talk about People's Disease Awareness, Attitudes, Behaviors and the Impact of Physical and Mental Health. Int. J. Environ. Res. Public Health 2020, 17, 4694. [CrossRef] [PubMed]

34. Krammer, F.; Srivastava, K.; Simon, V. Robust spike antibody responses and increased reactogenicity in seropositive individuals after a single dose of SARS-CoV-2 mRNA vaccine. N. Engl. J. Med. 2021, 384, 1372-1374. [CrossRef]

35. Ciotti, J.R.; Valtcheva, M.V.; Cross, A.H. Effects of MS disease-modifying therapies on responses to vaccinations: A review. Mult. Scler. Relat. Disord. 2020, 45, 102439. [CrossRef] [PubMed]

36. Day, T.; Gandon, S.; Lion, S.; Otto, S.P. On the evolutionary epidemiology of SARS-CoV-2. Curr. Biol. 2020, 30, R849-R857. [CrossRef]

37. Tirachini, A.; Cats, O. COVID-19 and public transportation: Current assessment, prospects, and research needs. J. Public Transp. 2020, 22, 1-21. [CrossRef]

38. The Government of Guangdong Province, China. Guangdong Province Is Carrying Out the Planning and Construction of the Bicycle Lane System, Researching and Formulating Technical Specifications for Parking Areas, and Strictly Controlling the Incremental Release of Shared Bicycles. Available online: http:/ / www.gd.gov.cn/gdywdt/bmdt/content/post_157375.html (accessed on 13 November 2021).

39. Chen, A.-J. After the Epidemic, Who Can Take the Lead in the Sharing Economy and Private Transportation? 2020. Available online: https:/ / kantar.com.tw /MailSources/InfoPulse/2020/COVID-19/Kantar_Taiwan_COVID-19_Report5_transportation. pdf (accessed on 21 September 2021).

40. iiMedia Research. 2021 China Shared Motorcycle Industry Research Report. 2020. Available online: https://report.iresearch.cn/ wx / report.aspx?id=2961 (accessed on 30 November 2021).

41. Shi, Y.-T. From China's Shared Bicycle ofo to Uber in the United States, is the Sharing Economy a Crisis or a Turning Point under the Epidemic? 2020. Available online: https:/ /www.storm.mg/article/2790775?page=1 (accessed on 21 September 2021).

42. Rauws, R.; van Lierop, D. Returning to Public Transit after an Epidemic. Findings, 1-9. 2020. Available online: https: / / findingspress.org/article/18328-returning-to-public-transit-after-an-epidemic (accessed on 30 November 2021).

43. National Bureau of Statistics of China. The Seventh National Population Census of China. 2020. Available online: http: //www.stats.gov.cn/tjsj/zxfb/202105/t20210510_1817178.html (accessed on 30 November 2021).

44. iiMedia Research. 2020 China Shared Motorcycle Safety Management Research Report. 2020. Available online: https://www. mouse0232.cn/2020zhongguogongxiangdiandancheanquanguanlizhuantiyanjiubaogao.html (accessed on 21 September 2021).

45. Hsu, C.-H.; Lin, H.-H.; Jhang, S.-W.; Lin, T.-Y. Does environmental engineering help rural industry development? Discussion on the impact of Taiwan's "special act for forward-looking infrastructure" on rural industry development. Water 2020, $12,3311$. [CrossRef]

46. Everyday Ethics for Local Officials. Being Less Than Forthright about an Agency's. Decision: The Conditioning-a-Project-to-Death. Example. 2002. Available online: https:/ / www.ca-ilg.org/sites/main/files/file-attachments/resources_Conditioning_Project_ June_02_0.pdf?1436996263 (accessed on 21 September 2021).

47. Lin, H.-H.; Lee, S.-S.; Perng, Y.-S.; Yu, S.-T. Investigation about the Impact of Tourism Development on a Water Conservation Area in Taiwan. Sustainability 2018, 10, 2328. [CrossRef]

48. $\mathrm{Hu}, \mathrm{H}$. Harmonious Relationship-Management Based on Human Relationships. In Principles of Chinese Management; Management for Professionals; Springer: Berlin/Heidelberg, Germany, 2021. [CrossRef]

49. Tech, R.R.M.; Theophilos, C. Preventing Bullying: A Manual for Teachers in Promoting Global Educational Harmony; Balboa Press: Bloomington, IN, USA, 2020.

50. Averill, J.R.; More, T.A. Happiness. In Handbook of Emotions; Lewis, M., Haviland, J.M., Eds.; The Guilford Press: New York, NY, USA, 1993; pp. 617-629.

51. Berridge, K.C. Evolving Concepts of Emotion and Motivation. Front. Psychol. 2008, 9, 1647. [CrossRef]

52. Sthapit, E. Memories of gastronomic experiences, savoured positive emotions and savouring processes. Scand. J. Hosp. Tour. 2017, 19, 115-139. [CrossRef]

53. Andrews, F.M.; Withey, S.B. Social Indicators of Well-Being: Americans' Perceptions of LIFE Quality; Springer: Berlin/Heidelberg, Germany, 2012. [CrossRef]

54. Samuel, R.; Hadjar, A. How Welfare-State Regimes Shape Subjective Well-Being Across Europe. Soc. Indic. Res. 2015, 129 , 565-587. [CrossRef] 
55. Wang, E.S.T.; Chen, L.S.L.; Lin, J.Y.C.; Wang, M.C.H. The relationship between leisure satisfaction and life satisfaction of adolescents concerning online games. Adolescence 2008, 43, 177-184. Available online: https:/ / pubmed.ncbi.nlm.nih.gov/184470 $89 /$ (accessed on 21 September 2021). [PubMed]

56. Yu, J.-H.; Lin, H.-H.; Huang, J.-M.; Wu, C.-H.; Tseng, K.-C. Under Industry 4.0, the current status of development and trend sports industry combining with cloud technology. Math. Prob. Eng. 2020, 2020, 1-16. [CrossRef]

57. Vecchio, G.; Tricarico, L. May the Force move you: Roles and actors of information sharing devices in urban mobility. Cities 2019, 88, 261-268. [CrossRef]

58. Dreyer, B.C.; Coulombe, S.; Whitney, S.; Riemer, M.; Labbé, D. Beyond Exposure to Outdoor Nature: Exploration of the Benefits of a Green Building's Indoor Environment on Wellbeing. Front. Psychol. 2018, 9, 1583. [CrossRef]

59. Oliveira-Castro, J.M. Behavior Analysis and Psychological Concepts: Commentary on Foxall's Intentional Behaviorism. In Contemporary Behaviorisms in Debate; Zilio, D., Carrara, K., Eds.; Springer: Cham, Switzerland, 2021. [CrossRef]

60. Uyaroğlu, D. A Performance Evaluation Tool for Inclusiveness in University Campus Outdoor Spaces. Megaron 2021, 16, 197-211. [CrossRef]

61. Chua, B.L.; Kim, H.C.; Lee, S.; Han, H. The role of brand personality, self-congruity, and sensory experience in elucidating sky lounge users' behavior. Tour. Mark. 2018, 36, 29-42. [CrossRef]

62. Horng, J.S.; Hsu, H. A holistic aesthetic experience model: Creating a harmonious dining environment to increase customers' perceived pleasure. J. Hosp. Tour. Manag. 2020, 45, 520-534. [CrossRef]

63. Alexander, B.; Cano, M.B. Futurising the Physical Store in the Omnichannel Retail Environment. In Exploring Omnichannel Retailing; Piotrowicz, W., Cuthbertson, R., Eds.; Springer: Cham, Switzerland, 2019. [CrossRef]

64. Kang, J. Identifying antecedents and consequences of well-being: The case of cruise passengers. Tour. Manag. Perspect. 2019, 33, 100609. [CrossRef]

65. Lin, M.-C. A Study of the Relationship between the Environmental Experience, Attitude and Behavior Intention of Elementary School Children-A Case of Participants in Jia-Jian-Tan Environmental Ecological Park. Master's Thesis, TOKO University, Chiayi, Taiwan, 2016.

66. Dewaele, J.M.; MacIntyre, P. The predictive power of multicultural personality traits, learner and teacher variables on foreign language enjoyment and anxiety. In Evidence-Based Second Language Pedagogy; Informa UK Limited: London, UK, 2019. [CrossRef]

67. Stebbins, R.A. Leisure and the positive psychological states. J. Posit. Psychol. 2017, 13, 8-17. [CrossRef]

68. Xu, H.; Yuan, M.; Li, J. Exploring the relationship between cycling motivation, leisure benefits and well-being. Int. Rev. Spat. Plan. Sustain. Dev. 2019, 7, 157-171. [CrossRef]

69. Pai, C.K.; Liu, Y.; Kang, S.; Dai, A. The role of perceived smart tourism technology experience for tourist satisfaction, happiness and revisit intention. Sustainability 2020, 12, 6592. [CrossRef]

70. Matsumoto, H.; Sato, S.; Asada, A.; Chiashi, K. Exploring the relationship among leisure engagement, affective and cognitive leisure involvement, and subjective happiness: A mediating role of leisure satisfaction. World Leis. J. 2018, 60, 111-126. [CrossRef]

71. Ellis, G.D.; Jiang, J.; Freeman, P.A.; Lacanienta, A.; Jamal, T. Leisure as immediate conscious experience: Foundations, evaluation, and extension of the theory of structured experiences. J. Leis. Res. 2020, 51, 581-600. [CrossRef]

72. Zhou, B.; Zhang, Y.; Dong, E.; Ryan, C.; Li, P. Leisure satisfaction and quality of life of residents in Ningbo, China. J. Leis. Res. 2021, 52, 469-486. [CrossRef]

73. Cho, H. Importance of leisure nostalgia on life satisfaction and leisure participation. Serv. Ind. J. 2020, 1-2, 90-109. [CrossRef]

74. Sato, M.; Jordan, J.S.; Funk, D.C.; Sachs, M.L. Running involvement and life satisfaction: The role of personality. J. Leis. Res. 2018, 49, 28-45. [CrossRef]

75. Chang, Y.-C.; Yeh, T.-M.; Pai, F.-Y.; Huang, T.-P. Sport activity for health!! The effects of karate participants' involvement, perceived value, and leisure benefits on recommendation intention. Int. J. Environ. Res. Public Health 2018, 15, 953. [CrossRef]

76. Tian, H.B.; Qiu, Y.J.; Lin, Y.Q.; Zhou, E.T.; Fan, C.Y. The Role of Leisure Satisfaction in Serious Leisure and Subjective Well-Being: Evidence from Chinese Marathon Runners. Frontiers in Psychology. Front. Psychol. 2020, 11, 581908. [CrossRef]

77. Quarmby, T.; Sandford, R.; Pickering, K. Care-experienced youth and positive development: An exploratory study into the value and use of leisure-time activities. Leis. Stud. 2019, 38, 28-42. [CrossRef]

78. Williams, R.B.; Slak-Valek, N. Pokémon GO is serious leisure that increases the touristic engagement, physical activity and sense of happiness of players. Inf. Technol. Tour. 2019, 21, 515-533. [CrossRef]

79. Mouratidis, K. Built environment and leisure satisfaction: The role of commute time, social interaction, and active travel. J. Transp. Geogr. 2019, 80, 102491. [CrossRef]

80. Francken, D.A.; van Raaij, W.F. Satisfaction with leisure time activities. J. Leis. Res. 1981, 13, 337-352. [CrossRef]

81. Ragheb, M.G.; Griffith, C.A. The contribution of leisure participation and leisure satisfaction to life satisfaction of older persons. J. Leis. Res. 1982, 14, 295-306. [CrossRef]

82. Li, H.; Li, W.; Wang, L.; Lv, L. Public satisfaction evaluation of urban water environment treatment public-private partnership project: A case study from China. Int. J. Build. Pathol. Adapt. 2020, 39, 407-432. [CrossRef]

83. Chen, Z.; Hu, Y.; Li, J.; Wu, X. Optimal deployment of electric bicycle sharing stations: Model formulation and solution technique. Networks and Spatial Economics. Netw. Spat. Econ. 2019, 20, 99-136. [CrossRef]

84. Liu, Z.; Ma, L.; Zhu, Y.; Ji, W. An investigation on responsible innovation in the emerging shared bicycle industry: Case study of a Chinese firm. J. Open Innov. Technol. Mark. Complex. 2019, 5, 42. [CrossRef] 
85. Guidon, S.; Becker, H.; Dediu, H.; Axhausen, K.W. Electric bicycle-sharing: A new competitor in the urban transportation market? An empirical analysis of transaction data. Transp. Res. Rec. J. Transp. Res. Board 2019, 2673, 15-26. [CrossRef]

86. Corno, M.; Duz, A.; Savaresi, S.M. Design of a Charge-Sustaining Energy Management System for a Free-Floating Electric Shared Bicycle. IEEE Trans. Control. Syst. Technol. 2021, 24,1-13. [CrossRef]

87. Li, C.; Dai, Z.; Peng, W.; Shen, J. Green travel mode: Trajectory data cleansing method for shared electric bicycles. Sustainability 2019, 11, 1429. [CrossRef]

88. Liu, P.; Ding, Y.; Fu, T.; Li, D. Joint Resource Optimization of Shared Electric Bicycles in Smart Cities. In Proceedings of the 2017 IEEE International Symposium on Parallel and Distributed Processing with Applications and 2017 IEEE International Conference on Ubiquitous Computing and Communications (ISPA/IUCC), Guangzhou, China, 12-15 December 2017. [CrossRef]

89. He, Y.; Song, Z.; Liu, Z.; Sze, N.N. Factors influencing electric bike share ridership: Analysis of Park City, Utah. Transp. Res. Rec. J. Transp. Res. Board 2019, 2673, 12-22. [CrossRef]

90. Li, L.; Zhu, B.; Jiang, M.; Cai, X.; Lau, A.K.W.; Shin, G.-C. The role of service quality and perceived behavioral control in shared electric bicycle in China: Does residual effects of past behavior matters? Environ. Sci. Pollut. Res. 2020, 27, 24518-24530. [CrossRef] [PubMed]

91. Wild, K.; Woodward, A. Why are cyclists the happiest commuters? Health, pleasure and the e-bike. J. Transp. Health 2019, 14, 100569. [CrossRef]

92. Li, Q.; Chen, H. The Relationship between Human Well-Being and Carbon Emissions. Sustainability 2021, 13, 547. [CrossRef]

93. Galli, A.; Iha, K.; Pires, S.M.; Mancini, M.S.; Alves, A.; Zokai, G.; Lin, D.; Murthy, A.; Wackernagel, M. Assessing the ecological footprint and biocapacity of Portuguese cities: Critical results for environmental awareness and local management. Cities 2019, 96, 102442. [CrossRef]

94. Ochieng, P.A. An analysis of the strengths and limitation of qualitative and quantitative research paradigms. Prob. Educ. 21st Century 2009, 13, 13-18.

95. Berry, N.; Lobban, F.; Bucci, S. A qualitative exploration of service user views about using digital health interventions for self-management in severe mental health problems. BMC Psychiatry 2019, 19, 35. [CrossRef]

96. Cypress, B. Qualitative Research Methods. Dimens. Crit. Care Nurs. 2018, 37, 302-309. [CrossRef] [PubMed]

97. Wu, M.-L.; Tu, J.-T. SPSS and Statistical Application Analysis, 2nd ed.; Wunan Publishing House: Taipei, Taiwan, 2017.

98. Geng, Y.; Ji, W.; Lin, B.; Zhu, Y. The impact of thermal environment on occupant IEQ perception and productivity. Build. Environ. 2017, 121, 158-167. [CrossRef]

99. Stinson, E.J.; Krakoff, J.; Gluck, M.E. Depressive symptoms and poorer performance on the Stroop Task are associated with weight gain. Physiol. Behav. 2018, 186, 25-30. [CrossRef]

100. Gursoy, D.; Jurowski, C.; Uysal, M. Resident Attitudes: A structural odeling approach. Ann. Tour. Res. 2002, 20, 79-105. [CrossRef]

101. Strauss, A.; Corbin, J. Basics of Qualitative Research: Grounded Theory Procedures and Techniques; Sage: Newbury Park, CA, USA, 1990.

102. Janesick, V.J. The choreography of qualitative research design: Minuets, improvisations, and crystallization. In Handbook of Qualitative Research; Denzin, N.K., Lincoln, Y.S., Eds.; Sage: Thousand Oaks, CA, USA, 2000; pp. 379-399.

103. Ajzen, I. The Theory of Planned Behavior. Organ. Behav. Human Decis. Process. 1991, 50, 179-211. [CrossRef]

104. Bower, I.; Tucker, R.; Enticott, P. Impact of built environment design on emotion measured via neurophysiological correlates and subjective indicators: A systematic review. J. Environ. Psychol. 2019, 66, 101344. [CrossRef]

105. Li, G. The Variant Coronavirus Hits, Beijing Cuts Off Land and Air Traffic, One Person Is Diagnosed and Everyone Is Not Allowed to Move. 2021. Available online: https: / / www.rfi.fr/tw (accessed on 21 September 2021).

106. Luo, I.-C.; Lai, J.-H. There Are 153 High-Risk Zones in China that Have Blocked the Spread of the New Crown. 2021. Available online: https://money.udn.com/money/story/5603/5651191 (accessed on 21 September 2021).

107. MahdiNejad, J.D.; Azemati, H.; Habibabad, A.S. Religion and spirituality: Mental health arbitrage in the body of mosques architecture. J. Relig. Health 2020, 59, 1635-1651. [CrossRef] [PubMed]

108. Sweeting, B. Wicked Problems in Design and Ethics. In Systemic Design. Translational Systems Sciences; Jones, P., Kijima, K., Eds.; Springer: Tokyo, Japan, 2018; Volume 8. 